Volume 124 | Issue 2

Winter 2019

\title{
Contractual Incapacity and the Americans with Disabilities Act
}

Sean M. Scott

Follow this and additional works at: https://ideas.dickinsonlaw.psu.edu/dlr

Part of the Agency Commons, Civil Law Commons, Common Law Commons, Contracts Commons, Disability Law Commons, Law and Economics Commons, Law and Psychology Commons, Legal History Commons, Legal Writing and Research Commons, and the Legislation Commons

\section{Recommended Citation}

Sean M. Scott, Contractual Incapacity and the Americans with Disabilities Act, 124 DIck. L. REV. 253 (2020).

Available at: https://ideas.dickinsonlaw.psu.edu/dlr/vol124/iss2/2

This Article is brought to you for free and open access by the Law Reviews at Dickinson Law IDEAS. It has been accepted for inclusion in Dickinson Law Review by an authorized editor of Dickinson Law IDEAS. For more information, please contactlja10@psu.edu. 


\title{
Articles
}

\section{Contractual Incapacity and the Americans with Disabilities Act}

\author{
Sean M. Scott*
}

\section{Abstract}

The doctrine of contractual incapacity allows people with mental disabilities to avoid their contractual liability. Its underlying premise is that the law has an obligation to protect people with such disabilities both from themselves and from unscrupulous people who would take advantage of them; mental incapacity provides this protection by rendering certain contracts unenforceable. The Disability Rights Movement ("DRM"), however, has challenged such protective legal doctrines, as they rest on outmoded concepts about people with mental disabilities.

This essay argues that the mental incapacity doctrine undermines the goals of the DRM and the legislative goals of the Americans with Disabilities Act. First, the doctrine reinforces stereotypes about people with mental disabilities, contributing to the negative social construction of disability. Second, it contributes to the social exclusion of people with mental disabilities, as

\footnotetext{
* Professor of Law, Loyola Law School, Los Angeles. My thanks to Susan Bahkshian, Alexander Boni-Saenz, Allison Carey, Victor Gold, Danielle Hart, Eve Hill, and Justin Levitt for their insightful suggestions and comments. Additional thanks to Rachel Ellis, Tanaz Irani, and Amber Madole for their excellent research assistance and to the participants at KCON XIII, the 2018 International Conference on Contracts.
} 
the threat of contract rescission discourages commerce with people with mental disabilities. Third, the doctrine unjustifiably imposes a requirement of rationality upon transactions entered into by people with mental disabilities. Finally, the doctrine demeans people with disabilities by shielding them from the risk-taking that is an integral part of life.

To mitigate the harm caused by contractual incapacity I propose that the doctrine be restricted to people who were subject to a plenary guardianship when they entered into the contract. Such a restriction is an imperfect proposal, but it strikes a better balance between the rights of people with mental disabilities and the mental incapacity doctrine than currently exists.

\section{TABle of CONTENTS}

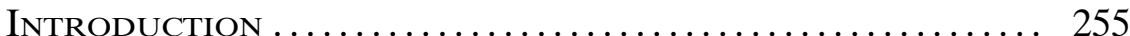

I. The Doctrine of Mental Incapacity in Contract Law ................................. 257

A. Historical Overview ....................... 257

B. Standards for Measuring Mental Incapacity ....... 262

II. Discrimination Under the ADA ............... 265

III. The Questionable Value of the Mental INCAPACITY Doctrine IN Light OF THE ADA AND THE DRM ................................ 268

A. The Mental Incapacity Doctrine, Social

Construction of Disability, and Stereotyping....... 269

1. Disability as Pathology.................... 271

2. People with Disabilities as Objects of Pity ... 274

3. Disability Drift.......................... 274

B. Deconstructing Disability: The DRM and the ADA................................ 280

C. Mental Incapacity Doctrine, Exclusion, and Integration ............................ 284

D. Rationality and Mental Incapacity............. 290

1. Policing Through Rationality ............... 290

2. Behavioral Law and Economics-Decision Making Is Irrational ..................... 297

3. Rationality, Autonomy, and the Dignity of Risk.................................. 302

E. Consequences .............................. 305

IV. Alternatives to Mental Incapacity ........... 310

A. Undue Influence ........................... 310

B. Unconscionability .......................... 315

CoDA . . . ........................................ 317 


\section{INTRODUCTION}

There has been some form of contractual mental incapacity doctrine since Justinian ruled the Roman Empire. ${ }^{1}$ Its contours have changed over time, but at its core is the principle that the law should protect those with mental disabilities from their own poor judgment and the unscrupulousness of others. By contrast, the Americans with Disabilities Act ("ADA") 2 is relatively new- Congress enacted the ADA in 1990. The ADA rejects the idea that people with mental disabilities need protection, challenges the subordinate status of people with disabilities, and advocates for the nondiscriminatory treatment of those with disabilities. This essay explores these two doctrines, their relationship, and the underlying values they each represent.

Exploration of the mental incapacity doctrine, the ADA, and the Disability Rights Movement ("DRM") has led me to argue the following: the mental incapacity doctrine, as currently constituted, is outmoded and should be limited to people with mental disabilities who were subject to a plenary guardianship when they entered into the contract at issue. I offer two primary arguments to justify this limitation. First, the mental incapacity doctrine is inconsistent with the underlying policies and goals of the ADA and the DRM. The doctrine socially constructs disability identity by relying on and reifying disability stereotypes. It also disincentives providers of goods and services from entering into contracts with people with disabilities, undermining their ability to fully participate in and integrate into society. Second, it improperly invokes rationality as a basis for policing the agreements entered into by people with mental disabilities, an approach challenged by behavioral economics and the dignity of risk doctrine.

This essay will use the following hypothetical, which is largely based on an actual case, to explore my proposal of limiting the mental incapacity doctrine's applicability. In 2009, Randolph Renchard entered into a contract to purchase a luxury yacht. ${ }^{3}$ To make the purchase, he liquidated his trust fund and traded in his

1. Samuel J. Brakel et al., The Mentally Disabled and the Law 9 (3d ed. 1985); W.G.H. Cook, Mental Deficiency and the English Law of Contract, 21 Colum. L. Rev. 424, 426 (1921). Gaw argues that there is evidence that there was Roman Law on the subject even prior to Justinian's rule. Albert C. Gaw, The Legal Status of the Deaf: The Development of the Rights and Responsibilities of Deaf-Mutes in the Laws of the Roman Empire, France, EnGLAND, AND AMERICA 10 (1907).

2. 42 U.S.C. $\S \S 12101-12213$ (2012).

3. Renchard v. Prince William Marine Sales, Inc., 87 F. Supp. 3d 271, 274 (D.D.C. 2015). 
previous boat for a down payment. Mr. Renchard then financed the yacht through the Prince William Marine Sales, Inc. After purchasing the yacht for $\$ 1.4$ million, Mr. Renchard began incurring charges for maintenance and upgrades that ultimately accrued to approximately $\$ 73,000$. Prince William alleged Mr. Renchard failed to pay for these charges and failed to honor subsequent agreements concerning these arrearages, asserting this was the basis for repossession and sale of the yacht to an unrelated third party. ${ }^{4}$

Mr. Renchard sued Prince William on several counts, including wrongful repossession and unjust enrichment. He argued, inter alia, that he did not have the mental capacity to enter into any of the contracts with the defendant. In his original complaint, $\mathrm{Mr}$. Renchard described himself as being "profoundly and pre-linguistically deaf and [as] us[ing] American Sign Language for daily communication."5 Mr. Renchard also alleged he had learning disabilities. ${ }^{6}$ Prince William filed a motion to dismiss, based, in part, on the argument Mr. Renchard fully understood the transactions entered into regarding the yacht. The court partially denied the defendant's motion to dismiss, arguing

[t]here is a material factual dispute as to whether the plaintiff could enter into a valid contract by reason of his mental and physical disabilities, and, consequently, whether the note regarding his Account and later Bill of Sale are sufficient to prove that the plaintiff was able to understand the consequences of his actions. $^{7}$

The court's finding echoed the classic test used to measure mental incapacity: does the person seeking to avoid the contract had the cognitive ability to understand the nature of the transaction? ${ }^{8}$ If Mr. Renchard established his mental incapacity, then the court would have avoided his contract based on the mental incapacity doctrine.

Mr. Renchard attempted to amend his original complaint by adding a cause of action for discrimination under Title III of the ADA. Title III prohibits certain private actors from discriminating based on disability. Because defendant Prince William Marine Sales, Inc. agreed to sell the yacht to plaintiff Mr. Renchard and to finance it, and because injunction is the only remedy provided for

4. Id. at 275-76. 2014).

5. Renchard v. Prince William Marine Sales, Inc., 28 F. Supp. 3d 1, 3 (D.D.C.

6. Id. at 3 .

7. Renchard, 87 F. Supp. 3d at 281.

8. This test will be developed more fully in Section IV, infra. 
the violation of Title III, ${ }^{9} \mathrm{Mr}$. Renchard was unable to add this cause of action to his complaint.

While a collision between the mental incapacity doctrine and the ADA was avoided in Renchard, a slight variation could bring these two doctrines into direct conflict. Assume that after the court's holding, the seller/lender defendant, apprehensive of another potential lawsuit, imposed additional screening requirements on people whom it perceived to have a mental disability. This seller/lender might use this strategy to manage anxiety about the heightened risk of default or contract avoidance and rescission based on mental incapacity. These additional requirements would arguably violate Title III of the ADA and give potential purchasers a cause of action for discrimination under the Act-this is especially true if a seller/lender refused to contract with someone because of their mental disability. This hypothetical provides an opportunity to review the mental incapacity doctrine and its value in light of the DRM and the ADA. The language of both the DRM and the ADA directly conflict with the mental incapacity doctrine, as do the principles these doctrines represent. Thus, I conclude that the mental incapacity doctrine should yield to the DRM and the ADA. ${ }^{10}$

Following this Introduction, Part II provides a historical overview of the mental incapacity doctrine and the standards used to measure incapacity. Part III provides an overview of the ADA provisions that govern private entities acting in a public capacity. Part IV considers arguments that support revising the doctrine in ways that take into account the values of the DRM and the ADA. Part $\mathrm{V}$ briefly considers contract doctrines that may provide a reasonable alternative to the mental incapacity doctrine. Part VI ends with a coda about the evolving relationship between mental incapacity, the DRM, and the ADA.

\section{The Doctrine of Mental Incapacity in Contract Law}

\section{A. Historical Overview}

The freedom to contract is a concept fundamental to contract law and allows parties to enter freely into any bargains they choose with little interference from courts. Traditionally, the courts medi-

9. Renchard, 87 F. Supp. $3 d$ at 279. For the ADA section specifying injunctive relief as the sole remedy for violation of Title III, see 42 U.S.C. § 12188.

10. For an insightful, complementary article that explores the reconceptualization of the mental incapacity doctrine in the context of sexuality see generally Alexander A. Boni-Saenz, Sexuality and Incapacity, 76 Oнго Sт. L.J. 1201 (2015). 
ate contractual disputes to uphold procedural integrity-that is, courts ensure transactions conform to the legal requirements of formation, performance, breach, and remedies. ${ }^{11}$ Under classical contract theory, courts are constrained in policing the substance of the exchange. ${ }^{12}$ There have always been exceptions to this general rule, however. ${ }^{13}$ Pursuant to the mental incapacity exception, courts may delve beneath the mechanics of contract formation. When a person with questionable capacity enters into a transaction, the court may review the substance of that transaction to ensure the other contracting party has not taken advantage of her.

The history of the mental incapacity doctrine reveals judicial and societal ambivalence not only about the doctrine but about mental illness and disability more generally. ${ }^{14}$ This ambivalence has many sources. Historically, skepticism may have been based on a society-wide lack of scientific knowledge about mental illness and disability. ${ }^{15}$ Individuals exhibiting signs of mental illness or disability are often pitied, feared, or condemned as evil by society. This lack of understanding has created disbelief about the existence of mental disabilities. Such disbelief perpetuates the idea that an individual may fake symptoms of illness to avoid legal liability. ${ }^{16} \mathrm{Al}$ though scientific findings have deepened the societal, and thus

11. See E. Allan Farnsworth, United States Contract Law 70-71, 91 (1991); Grant Gilmore, The Death of Contract 15 (1974).

12. Gilmore, supra note 11 , at 15 .

13. Lawrence M. Friedman, Contract Law in America 19-20 (1965); see also FARnsworth, supra note 11, at 98; Melvin Eisenberg, The Bargain Principle and Its Limits, 95 HARv. L. Rev. 741, 742 (1982).

14. This societal and legal discomfort is not one that Americans have outgrown. "The entire legal system makes assumptions about persons with mental disabilities ... [t]hese assumptions reflect our fears and apprehensions about mental disability, persons with mental disability and the possibility that we may become mentally disabled." Michael L. Perlin, "Half-Wracked Prejudice Leaped Forth": Sanism, Pretextuality, and Why and How Mental Disability Law Developed as it Did, 10 J. Contemporary Legal Issues 3, 17 (1999).

15. See Brakel ET AL., supra note 1 , at 16 . Brakel notes:

[T] he development of the law as it affects the rights of the mentally disabled has been dependent on many factors [including] ... the state of the medical knowledge of the cause, care, and proper treatment of the mentally disabled .... and the legal profession's awareness of the social realities of mental disability. ...

Id. Justice Kennedy commented on societal ambivalence in his concurrence in Olmstead v. L.C., 527 U.S. 581, 608 (1999) (Kennedy, J., Concurring).

16. BRAKel ET AL., supra note 1, at 18. Skepticism about the existence of disability, whether mental or physical, continues to be a public policy norm; see Jacobus tenBroek \& Floyd W. Matson, The Disabled and the Law of Welfare, 54 CALIF. L. REv. 809, 830 (1966) ("[T]he disabled client finds himself confronted with a presumption not of innocence and eligibility [for public benefits] but of guilt and probable fraud."). 
legal, understanding of mental disabilities,$^{17}$ the difficulty in defining mental illness and mental disability continues, raising ongoing questions about the role of the law and civil and criminal accountability for those with mental illnesses and disabilities. ${ }^{18}$

Despite skepticism, the legal field did acknowledge it ought to consider the enforceability of contracts entered into by people with mental disabilities. The Mentally Disabled and the Law briefly traces the history of Western laws governing mental disability. Explanations for what causes mental disabilities have shifted nonlinearly, from religious causes, to medical or social causes (or a combination of both). In ancient times, and again during the Middle Ages, people with mental disabilities were thought to be possessed by demons and were treated accordingly. ${ }^{19}$ Rejecting the idea of demon possession, both Greek and Roman societies developed medical explanations and instituted corresponding changes in the treatment of mental disabilities. ${ }^{20}$

Regardless of the disability's cause, societies grapple with the legal status of individuals with disabilities. The concept of contractual incapacity arose under Roman Law. Initially, the law focused on preventing certain people from entering into valid contracts. According to Roman Law, a contract entered into by a person with a mental disability was void, as this person was unable to consent to the agreement due to the disability. ${ }^{21}$ The Visigothic Code continued this prohibition but recognized that a person with a mental disability could have periods of lucidity and that contracts made during such periods were valid. ${ }^{22}$ As Western society's understanding of mental disabilities increased, courts created more categories of the legally disabled, and the rights and responsibilities of individuals belonging to those categories became more nuanced. ${ }^{23}$ Regardless, English and American courts were still concerned about

17. See Brakel et Al., supra note 1, at 15-16; Robert M. Brucken et al., Mental Illness and the Law of Contracts, 57 Мich. L. Rev. 1020, 1033 (1959).

18. See Nat'l. Council on Disability, Beyond Guardianship: Toward Alternatives that Promote Greater Self-Determination 82 (2018); Brakel ET AL., supra note 1, at 16-20. See generally Jan Ellen Rein, Clients with Destructive and Socially Harmful Choices-What's an Attorney to Do?: Within and Beyond the Competency Construct, 62 Ford. L. REv. 1101 (1994).

19. Brakel et al., supra note 1, at 10; Albert Deutsch, The Mentally ILl IN AMERICA 1-2 (2d ed. 1949) (indicating remedies for mental disabilities included exorcism).

20. BRAKel Et AL., supra note 1, at 9-10; Brucken et al., supra note 17.

21. BRAKel ET AL., supra note 1, at 10.

22. $I d$.

23. BRAKEL ET AL., supra note 1, at 10-18; Brucken et al., supra note 17, at 1023 
preventing or prohibiting individuals with disabilities from entering into contracts. For instance, courts denied deaf ${ }^{24}$ people the capacity to enter into contracts by deeming them idiots under the law. ${ }^{25}$

By the mid-1800s, the English courts indicated that mental incapacity could be raised as a defense to the enforcement of a contract if one party knew or should have known of the other party's questionable capacity. ${ }^{26}$ American courts followed suit. For instance, in the early American case Burke v. Allen, ${ }^{27}$ the Supreme Court of New Hampshire noted in dicta that insanity could be raised as a defense to the enforcement of a promissory note. ${ }^{28}$ The court in Farmers Bank v. Public Service Company ${ }^{29}$ succinctly traced the history of the mental incapacity doctrine in contracts, noting the doctrine was initially rejected by English courts that argued "no man of full age shall in any plea set up his own insanity as a defense to his act." 30 The courts ultimately accepted this plea: "[t]he doctrine that a person shall not be allowed to stultify himself ... is now exploded, and under modern decisions the right of an alleged insane person to avoid his contracts generally depends upon the degree of his incapacity." ${ }^{11}$

This shift in judicial willingness to accept the plea was tempered by concerns about the need for certainty in the enforceability of contracts - an idea motivated by the industrialization of America in the 19th century. America's economy shifted from agriculture to

24. There is an ongoing debate about whether and when to capitalize the word "deaf." According to Gallaudet University, lowercase deaf can be used to identify the audiological condition of being unable to hear, hard of hearing, or when the deaf person indicates that this is their preference. Uppercase Deaf is used to describe those who identify as belonging to a cultural and linguistic minority, or those who indicate that this is their preference. FAQ, Gallaudet U., http:/ /bit.ly/GallU [https://perma.cc/U9UQ-ZAUV] (last visited Nov. 7, 2018). The University does not take a position on which to use; nor does the National Association of the Deaf. The National Center on Disability and Journalism recommends using the lowercase to refer to the audiological condition, or when the person self-describes as deaf, and uppercase for those who identify as members of the Deaf community or self-describe as Deaf. Disability Language Style Guide, NAT'L CTr. ON DisABILITY \& JouRNALISM, http://bit.ly/NCDJStyle [https://perma.cc/3X4HWFG7] (last updated 2018). Because I do not know which of these past litigants would have chosen, I will opt to use the lowercase deaf throughout this essay.

25. Gaw, supra note 1, at 82; see Lowell J. Myers, The Law and the Deaf 50 (Max Friedman ed. 1967).

26. Molton v. Camroux, 2 Ex. 487, 154 Eng. Rep. 584 (1848), aff'd, 4 Ex. 17,

154 Eng. Rep. 1107 (1849); Brucken et al., supra note 1, at 1023.

27. Burke v. Allen, 29 N.H. 106 (1854).

28. Id. at 111.

29. Farmers Bank v. Pub. Serv. Co., 13 F. Supp. 548 (W.D. Ky. 1936).

30. Id. at 550 .

31. Id. 
manufacturing, and commercial law developed as a way to encourage this revolution. ${ }^{32}$ Contract law was concerned with the promotion of commerce and was connected intimately to the 19th century idea of the free market. ${ }^{33}$ Avoidance of liability created uncertainty about the enforceability of contracts. ${ }^{34}$ This uncertainty is bad for commerce, and the judiciary was skeptical of any doctrine that created doubt. ${ }^{35}$ The Restatement (Second) of Contracts continues to reflect this ambivalence, as it provides the competing policies of protecting the commercial expectations of the parties must be balanced against the societal interest in protecting those with a mental disability. ${ }^{36}$

Initially, the law was concerned primarily about the property of the person with questionable capacity rather than the treatment of the person. ${ }^{37}$ Correspondingly, the law focused on who should bear the cost and financial responsibility for those unable to provide for themselves economically due to their disability or society's response to their disability. ${ }^{38}$ The scope of the law expanded beyond pecuniary concerns, as it wrestled with, and continues to wrestle with, issues such as the degree to which a person with a mental disability

32. See Gilmore, supra note 11, at 8 ("Commercial law, to lawyers, means the law relating to the sale and distribution of goods-thus, the law of sales, the law of carriers, the law of shipping; to the modes of extending credit and making payment for goods sold - thus, the law of negotiable instruments. . . In a word, this is the law which the Industrial Revolution left in its wake."); see also, FARNswOrTH, supra note 11 , at 30 .

33. Friedman, supra note 13, at 20; FARnsworth, supra note 11, at 29-31.

34. The concern about preserving contracts to create certainty and to protect the expectations of contracting parties is explicitly referred to in the comments to section 15 of the Restatement (Second) of Contracts. Restatement (SECOND) OF Contracts $\S 15 \mathrm{cmt}$. a (Am. Law Inst. 1981). Courts also recognize this policy. See, e.g., Ortelere v. Teachers' Ret. Bd., 25 N.Y.2d 196, 205 (N.Y. 1969).

35. See FARnsworth, supra note 11, at 91.

36. Restatement (Second) of Contracts $\S 15 \mathrm{cmt}$. a.

37. Deutsch, supra note 19 , at 40 . The concern about the health and wellbeing of those with mental disabilities seems to have begun with the development of the field of psychiatry. As the field of knowledge grew, so too did the societal and legal concern about protecting those with mental disabilities. Previously, the societal concern focused on protecting society from the disabled; see BRAKEL ET AL., supra note 1 , at 14 .

38. One of the core projects of the Disability Rights Movement has been to challenge the medical model of disability. Many advocates adopt the social model of disability, which holds that it is not the disability itself that creates barriers to people but rather society's response or refusal to include those with challenges that creates the disability. For a discussion of the social model of disability, see JAMES I. Charlton, Nothing About Us Without Us 7-8 (1998); Arlene S. Kanter, The Law: What's Disability Studies Got to Do with It or an Introduction to Disability Legal Studies, 42 Colum. Hum. RTs. L. Rev. 403, 419-31 (Winter, 2011) [hereinafter Kanter, The Law]. 
may manage her assets and exercise rights such as marrying, voting, and entering into contracts.

The recent case of Jenny Hatch is illustrative. ${ }^{39}$ Ms. Hatch is a person with Down Syndrome. Her parents petitioned to place her in a guardianship with them appointed as her guardians. Ms. Hatch's parents alleged that she did not have the mental capacity to make decisions for herself, including decisions about finances, health, relationships, residence, and education. They sought complete control over every aspect of Ms. Hatch's life. In a remarkable decision, the court ordered a one-year limited guardianship that would later transition into a new model of supported decision-making. ${ }^{40}$ This case, and the court's decision to use a new model for balancing the interests of the person with questionable capacity and the interests of broader society, reflects the ongoing issue of how the law should intervene in cases involving persons with mental disabilities.

\section{B. Standards for Measuring Mental Incapacity}

The law presumes that a person who has not been adjudicated incompetent has the mental capacity to enter into a valid contract. ${ }^{41}$ Generally, contracts entered into by people who have been adjudicated legally incompetent due to a mental disability are void as a matter of law. ${ }^{42}$ In most jurisdictions, and under the Restatement (Second) of Contracts, contracts entered into by people who are mentally incapacitated to some degree, but who have not been de-

39. Theresa Vargas, Woman with Down Syndrome Prevails Over Parents in Guardianship Case, WAsh. Post, Aug. 2, 2013, https://wapo.st/1NSGlrm [https:// perma.cc/T2BH-872E].

40. Id. The concept of supported decision-making has emerged as a viable substitute for guardianships, both plenary and limited. It has received extensive attention, both domestically and internationally. For an introduction to the model, see generally NAT'L. CounCil ON DisABILITY, supra note 18; Nina A. Kohn et al., Supported Decision-Making: A Viable Alternative to Guardianship?, 117 PENN. ST. L. Rev. 1111 (Spring 2013); Michael L. Perlin, "Striking for the Guardians and Protectors of the Mind": The Convention on the Rights of Persons with Mental Disabilities and the Future of Guardianship Law, 117 Penn. St. L. Rev. 1159 (2013).

41. Butler v. Harrison, 578 A.2d 1098, 1098 (D.C. 1990); Citizens State Bank v. Ruebel, No. 10-1028, 2011 WL 3116243, at *4 (Iowa Ct. App. 2011); Estate of McGovern v. Commonwealth, 517 A.2d 523, 527 (Pa. 1986); Howard O. Hunter, Modern Law of Contracts § 2:14 (updated Mar. 2017).

42. See Kenai Chrysler Ctr., Inc. v. Denison, 167 P.3d 1240, 1248 (Alaska 2007); James B. Nutter \& Co. v. Black, 123 A.3d 535, 543 (Md. Ct. Spec. App. 2015); Breaux v. Allied Bank of Texas, 699 S.W.2d 599, 602 (Tx. App. 1985); RESTATEMENT (SECOND) OF Contracts $§ 13$ (Am. Law. Inst. 1981). 
clared legally incompetent, are voidable not void. ${ }^{43}$ One can be deemed legally incompetent if the mentally disabling condition satisfies the legal test for incompetency. ${ }^{44}$ For legal purposes, a majority of jurisdictions provide that mental incapacity can manifest either cognitively or volitionally. Under contract law, cognitive incapacity is defined as the inability to understand the nature of the transaction or its consequences. ${ }^{45}$ Volitional incapacity is defined as the inability to control one's actions related to the transaction, even though the individual intellectually appreciates the transaction and its consequences. ${ }^{46}$

The person claiming incompetency to avoid a contract has the burden of proving her incompetency and that she was incompetent at the time of contracting; ${ }^{47}$ a general claim of incompetency is insufficient to support a claim for rescission. ${ }^{48}$ Even a diagnosis of dementia or Alzheimer's disease, ${ }^{49}$ arteriosclerosis, ${ }^{50}$ or other men-

43. Erkins v. Alaska Tr., LLC, 355 P.3d 516, 519-20 (Alaska 2015); Atkinson v. McCulloh, 132 A. 148, 151 (Md. 1926); Farnum v. Silvano, 540 N.E.2d 202, 204 (Mass. App. Ct. 1989); Ortelere, 250 N.E.2d at 465; Faber v. Sweet Style Mfg. Corp., 242 N.Y.S.2d 763, 766 (N.Y. Sup. Ct. 1963); Breaux, 699 S.W.2d at 602; Hauer v. Union State Bank of Wautoma, 532 N.W.2d 456, 460 (Wis. Ct. App. 1995); Restatement (Second) of Contracts $\S 15 \mathrm{cmt}$. d; 5 Williston on CoNTRACTS $§ 10.3$ (4th ed. 2019); Lawrence A. Frolik \& Mary F. Radford, "Sufficient" Capacity: The Contrasting Capacity Requirements for Different Documents, 2 Nat'l Acad. Elder L. AtT'ys J. 303, 317 (2006). Some states have statutes that provide this standard. CAl. Civ. Code $\S \S 38,39$ (West 2019); Del. Code AnN. $\S 2705$ (West 2019); Ga. Code Ann. § 13-3-24 (West 2019); Idaho Code Ann. $\S 32-108$ (West 2019); N.D. Cent. Code Ann. § 14-01-02 (West 2019).

44. Henry Weihofen, Mental Incompetency to Contract or Convey, 39 S. CAL. L. REv. 211, 215 (1966).

45. See Brown v. United Mo. Bank, N.A., 78 F.3d 382, 386 (8th Cir. 1996) (citing McElroy v. Mathews, 263 S.W.2d 1, 10 (Mo. 1953)); Brisacher v. TracyCollins Trust Co., 277 F.2d 519, 522 (10th Cir. 1960); McAllister v. Schettler, 521 A.2d 617, 621 (Del. Ch. 1986) (citing G.A.S. v. S.I.S., 407 A.2d 253, 257 (Del. Fam. Ct. 1978)); Sparrow v. Demonico, 960 N.E.2d 296, 301 (Mass. 2012) (citing Wright v. Wright, 29 N.E. 380, 382 (Mass. 1885)); Restatement (Second) Of Contracts $§ 15$; Howard O. Hunter, Modern Law of Contracts § 2:14 (rev. ed. 1993) [hereinafter HUNTER].

46. Ortelere, 250 N.E.2d at 464-65; Blatt v. Manhattan Med. Grp., P.C., 519 N.Y.S.2d 973, 976 (N.Y. App. Div. 1987); Restatement (SECOnd) of Contracts $\S 15$.

47. Butler v. Harrison, 578 A.2d 1098, 1100-01 (D.C. 1990); Estate of McGovern v. Commonwealth, 517 A.2d 523, 526 (Pa. 1986); Dubree v. Blackwell, 67 S.W.3d 286, 289 (Tex. App. 2001).

48. See In re McCraw v. Watkins, 249 S.E.2d 202, 203 (Ga. 1978); Greathouse v. Vosburgh, 169 N.E.2d 97, 103-04 (Ill. 1960); Sutherland State Bank v. Furgason, 186 N.W. 200, 206 (Iowa 1922); In re Knutson's Estate, 82 N.W.2d 196, 199-200 (Wis. 1957); Weihofen, supra note 44, at 219.

49. In re Lewis-Pride, 330 B.R. 660, 662 (Bankr. N.D. Ill. 2005) (Alzheimer's); Stave v. Estate of Rutledge, 127 P.3d 365, 368-69 (Mont. 2005) (Alzheimer's); 
tally debilitating conditions such as depression ${ }^{51}$ or post-traumatic stress disorder ${ }^{52}$ will not alone support a finding of mental incompetency. ${ }^{53}$ In Rawlings v. John Hancock Mutual Life Insurance Company,${ }^{54}$ the husband of decedent Ms. Rawlings challenged her removal of her husband and substitution of her brother as the designated beneficiary on her life insurance policy. Ms. Rawlings was an alcoholic and in 1997 was diagnosed with senile dementia and depression; she changed her life insurance policy in 1998. Despite the prior diagnosis of dementia, the court upheld the decedent's change of beneficiary form. ${ }^{55}$

Conversely, the absence of a permanent, degenerative mental condition does not preclude a finding of mental incapacity. ${ }^{56}$ There must be either lay or medical testimony describing how, on the day of the transaction, the condition rendered the person mentally incompetent in accordance with the legal definition of incompetency. ${ }^{57}$ The claimant may also have to prove that the other contracting party had notice of the incompetency. ${ }^{58}$ The other party then has the burden of proving the contract was entered into in good faith, was fair, and was entered into before the complainant was adjudicated incompetent. ${ }^{59}$ Some courts put the burden on the person seeking to enforce the contract and require this individual show they had no notice of the incompetency. ${ }^{60}$ If the parties have performed under the contract, most courts add one more requirement to contract avoidance: the incompetent person must be able

Rawlings v. John Hancock Mut. Life Ins. Co., 78 S.W.3d 291, 297 (Tenn. Ct. App. 2001) (dementia).

50. Gindhart v. Skourtes, 530 P.2d 827, 829 (Or. 1975).

51. Cullinane v. Estate of Vene, No. 305030, 2012 WL 2362441, at *4 (Mich. Ct. App. June 21, 2012); Uribe v. Olson, 601 P.2d 818, 820 (Or. Ct. App. 1979). 2012).

52. Lang v. Tewksbury Twp., No. 10-2564, 2012 WL 503677, at *5 (D.N.J.

53. Uribe, 601 P.2d at 820; Brucken et al., supra note 17, at 1032; and cases cited therein.

54. Rawlings v. John Hancock Mut. Life Ins. Co., 78 S.W.3d 291 (Tenn. Ct. App. 2001).

55. Id. at 299. The court may have been influenced by the fact that the decedent's husband had earlier declared his intention to seek a divorce from the decedent.

56. Sparrow v. Demonico, 960 N.E.2d 296, 330-31 (Mass. 2012).

57. See Rawlings, 78 S.W.3d at 298; see also Sparrow, 960 N.E.2d at 304-05.

58. Atkinson v. McCulloh, 132 A. 148, 151 (Md. 1926); Faber v. Sweet Style Mfg. Corp., 242 N.Y.S.2d 763, 766 (N.Y. Sup. Ct. 1963); Restatement (SECOND) of Contracts $\S 15 \mathrm{cmt}$. b (Ам. Law Inst. 1981). But see Brown v. Fin. Enters. Corp., 188 B.R. 476, 485 (Bankr. D. Mass. 1995) (indicating avoidance of contract does not depend on knowledge of incompetence).

59. Faber, 242 N.Y.S.2d at 766; HunTER, supra note $45, \S 2: 15$.

60. HunTER, supra note 45, § 2:15. 
to restore the value of that which she has received. ${ }^{61}$ However, other courts have held that if the competent person knows of the incapacity, the court may not require the incompetent party to provide restitution. ${ }^{62}$

\section{Discrimination Under the ADA}

The ADA, enacted in 1990 and amended in $2008,{ }^{63}$ is deemed one of the most influential statutes enacted in the United States that governs the rights of the disabled. ${ }^{64}$ The ADA prohibits a broad range of actors from discriminating against people with disabilities, including public entities and private entities that provide public opportunities and services. Title III of the ADA is the primary provision discussed in this essay.

To bring a cause of action under Title III, the plaintiff must establish three elements. First, the person must be disabled within the meaning of the statute. Second, the defendant must be covered by the statute. And third, the disabled person must have been discriminated against based on her disability as defined within the statute. Having established the elements of the cause of action, the defendant may have a defense to liability as provided by the statute.

As to the first element, the ADA defines an individual as having a disability if ${ }^{65}$ 1) an individual has a physical or mental impairment that substantially limits one or more major life activities of such individual;2) an individual has a record of such impairment; or 3 ) the individual is being regarded as having such an impairment. ${ }^{66}$ The third prong of this definition is of particular interest for pur-

61. See Flach v. Gottschalk Co. of Balt. City, 41 A. 908, 909 (Md. 1898); Faber, 242 N.Y.S.2d at 766; Hauer v. Union State Bank, 532 N.W.2d 456, 464 (Wis. Ct. App. 1995); 5 Williston on Contracts $§ 10: 6$ (4th ed. 1990); Weihofen, supra note 44, at 231; HunTER, supra note 45, § 2:15.

62. See Kenai Chrysler Ctr., Inc. v. Denison, 167 P.3d 1240, 1248 (Alaska 2007); Pappert v. Sargent, 847 P.2d 66, 70 (Alaska 1993); Williston, supra note 61, § 10:6; 53 Aм. Jur. 2D Mentally Impaired Persons $\$ 165$ (2019).

63. ADA Amendments Act of 2008, Pub. L. 110-325, 122 Stat. 3553.

64. See Laura Rothstein \& Julia Irzyk, Disabilities and the Law $\S 1: 12$ (4th ed. 2015).

65. The EEOC has identified a list of impairments that will virtually always meet the definition of disability under the ADAAA, regardless of which prong of the statutory definition they are pled. This list includes "intellectual disability (formerly known as mental retardation), autism, major depression, bipolar disorder, post-traumatic stress disorder, obsessive-compulsive disorder, and schizophrenia." Questions and Answers on the Notice of Proposed Rulemaking for the ADA Amendments Act of 2008, in EEOC Compliance Manual, U.S. Equal Emp. OpPORTUNITY COMMISSION, 2009 WL 4782104 (2009).

66. 42 U.S.C. $\S 12102(1)(2012)$. 
poses of this essay. This "regarded as" prong is intended to cover two categories of individuals.

The first category includes individuals who have been discriminated against under the ADA and who are not disabled. ${ }^{67}$ These individuals are mistakenly categorized as being disabled and prohibited actions have been taken against them. In Horgan v. Simmons, ${ }^{68}$ the plaintiff challenged his firing under the ADA, arguing that the defendant fired him because he was HIV positive. The defendant argued the plaintiff failed to establish a cause of action under the ADA because his HIV status did not constitute a disability therein. The court noted that regardless of whether HIV status constituted a disability, the plaintiff established a cause of action under the ADA because the defendant regarded him as having a disability. ${ }^{69}$

The second category includes individuals who actually have a disability and were subjected to actions prohibited by the ADA. ${ }^{70}$ Individuals in this category may include people with disabilities who cannot easily meet the "substantially limits" or "major life activities" components contained in the first prong's definition of disability. ${ }^{71}$ Congress intended this category to specifically address the issue of discrimination against "individuals who are subject to myths, stereotypes[,] and biases about individuals with disabilities."72

As to the second requirement the defendant must prove under the ADA, Title III includes private entities that provide certain public accommodations. The Title III list of such providers is comprehensive and includes, among others, places of lodging, establishments serving goods or drinks, places of entertainment, and banks. $^{73}$ As to the third element, Title III of the ADA prohibits

67. Sch. Bd. of Nassau Cty. v. Arline, 480 U.S. 273, 279 (1987) (citing Southeastern Cmty. Coll. v. Davis, 442 U.S. 397, 405-06 n.6 (1979); Adair v. City of Muskogee, 823 F.3d 1297, 1304-06 (10th Cir. 2016) (containing a succinct discussion of the evolution of this ADA standard); DiGiosia v. Aurora Health Care, Inc., 48 F. Supp. 3d 1211, 1215 (E.D. Wis. 2014); Kevin Barry et al., Pleading Disability After the ADAAA, 31 Hofstra LAB. \& EMP. L. J. 1, 10-11 (2013).

68. Horgan v. Simmons, 704 F. Supp. 2d 814 (N.D. Ill. 2010).

69. Id. at 820 n. 4 .

70. See Estate of Murray v. UHS of Fairmount, Inc., No. 10-2561, 2011 WL 5449364, at *5 (E.D. Pa. Nov. 10, 2011); Dudley v. Hannaford Bros. Co., 146 F. Supp. 2d 82 (D. Me. 2001).

71. Arline, 480 U.S. at 283; Ruth Colker \& Paul D. Grossman, The Law of Disability Discrimination 50-51 (8th ed. 2013).

72. Colker \& Grossman, supra note 71, at 51; When is Individual Regarded as Having, or Perceived to Have, Impairment Within Meaning of Americans with Disabilities Act (42 U.S.C.A. $\S 12102(2)(C)), 148$ A.L.R. FeD. 305, 2 (2019).

73. 42 U.S.C. $\S 12181(7)(2012)$. 
private entities covered by the statute from discriminating against an individual "on the basis of disability in the full and equal enjoyment of the goods, services, facilities, privileges, advantages, or accommodations of any place of public accommodation by any person who owns, leases (or leases to), or operates a place of public accommodation." ${ }^{74}$ Additionally, Title III declares:

[It is] discriminatory to subject an individual or class of individuals on the basis of a disability or disabilities of such individual or class, directly, or through contractual, licensing, or other arrangements, to a denial of the opportunity of the individual or class to participate in or benefit from the goods, services, facilities, privileges, advantages, or accommodations of an entity. ${ }^{75}$

If the defendant is guilty of violating Title III, injunctive relief from future violations is the remedy available to a private citizen. ${ }^{76}$

Applying the definitions and other provisions of Title III to the hypothetical Renchard case, had Prince William Marine Sales, Inc. refused to sell the yacht to Mr. Renchard because he was a person with a mental disability, he could have asserted a cause of action for unlawful discrimination under the ADA. To do so, Mr. Renchard would have to establish that he was a person with a disability as defined by the statute. This would require him to show the following: 1) he has a mental or physical impairment; 2) the impairment impacts one or more major life activities; and 3) the impairment substantially limits the major life activities identified. ${ }^{77} \mathrm{Mr}$. Renchard could have used his profound deafness, coupled with his learning disabilities, to satisfy this requirement. The second element of the cause of action would be easy to satisfy; as a seller/ lender, Prince William would qualify as a private entity providing public accommodations within the purview of the statute. ${ }^{78}$ Third, the denial of the sale and the loan based on Mr. Renchard's disability would qualify as discriminatory acts prohibited by the statute, as this refusal would have denied him the opportunity to avail himself of the goods and services provided by the Prince William. The ADA prohibits parties from refusing to sell or make loans based on

74. Id. § 12182(a).

75. Id. § 12182(b)(1)(A)(i).

76. Id. $\S 12188(\mathrm{a})(1)$. The limitation of remedy for private citizens to injunctive relief has been criticized as limiting the effectiveness of Title III. Ruth Colker, ADA Title III: A Fragile Compromise, 21 Berkeley J. Emp. \& Lab. L. 377, 402-03 (2000).

77. 42 U.S.C. $\S 12102(2)$.

78. Id. $\S 12181(7)(\mathrm{F})$. 
an actual or perceived disability, and such actions would provide any potential purchaser with a cause of action under the ADA. ${ }^{79}$

\section{The Questionable Value of the Mental Incapacity Doctrine in Light of THE ADA AND THE DRM}

The hypothetical Renchard case, in which the seller/lender refuses to enter into a contract with a potential client due to perceived or actual disabilities, illustrates the facial and philosophical tension between the mental incapacity doctrine and the ADA, particularly in light of the DRM. This essay seeks to resolve the tension between the mental incapacity doctrine and the ADA by limiting the situations in which people with mental disabilities and their representatives can assert the doctrine. Specifically, I argue the mental incapacity doctrine should be raised only by those who have been adjudicated incompetent and were subject to a plenary guardianship $^{80}$ at the time they entered into the contract. ${ }^{81}$ In this section, I offer two principle arguments to support this proposal. First, restricting the doctrine would support the DRM goals of challenging stereotypic portrayals of people with mental disabilities and ensuring the total societal integration of people with disabilities. Second, relying on rationality to measure the validity of transactions entered into by people with mental disabilities is misguided, is challenged by behavioral economics, and undermines the autonomy of people with mental disabilities.

Parts A and B discuss the way in which the mental incapacity doctrine constructs disability by using disability myths and stereotypes and the response by the DRM and the ADA to this construction. Part $\mathrm{C}$ discusses the DRM goal of integration and the way in which the mental incapacity doctrine undermines this goal. Part D explores two challenges to rationality as a basis for justifying the use of the mental incapacity doctrine to intervene in contracts entered into by people with mental disabilities: 1) behavioral economics; and 2) the dignity of risk. Part E considers some of the

79. Id. § 12102(h); see Dudley v. Hannaford Bros. Co., 146 F. Supp. 2d 82, 85 (D. Me. 2001).

80. Guardianship here is used to encompass the two distinct, concepts of guardianships and conservatorships. Generally, guardianships confer authority on one person to act on behalf of the person subject thereto in personal matters such as health decisions. Conservatorships confer authority over the assets of the person who has been adjudicated incompetent.

81. Limiting the ability of those subject to a guardianship to enter into contracts is itself problematic. However, that topic warrants its own essay and thus while acknowledging the serious issues surrounding guardianship, they are beyond the scope of this essay. 
potential risks involved in restricting the mental incapacity doctrine as proposed in this essay.

\section{A. The Mental Incapacity Doctrine, Social Construction of Disability, and Stereotyping}

The mental incapacity doctrine socially constructs of the concept of disability. To say that disability is socially constructed does not mean it is not real. ${ }^{82}$ Such social construction results in tangible, significant consequences for the lives of people with disabilities. The mental incapacity doctrine supports the misperception that simply having a mental disability justifies restrictions on one's rights and liberties, including the ability to enter into a binding contract. ${ }^{83}$ Thus, its impact extends far beyond the actual number of people whose contracts are avoided based on the doctrine.

Most disability rights activists have adopted the social, as opposed to the medical, model of disability. ${ }^{84}$ The social model of disability is premised on the idea that identity is largely socially constructed. ${ }^{85}$ Thus, social, economic, religious, and political institutions all shape the identity of individuals with impairments:

[T] he social model of disability . . . holds that disability is not a physical condition pertaining to a 'defective' or 'inferior' or 'abnormal' body but rather a social condition brought about by so-

82. See Kimberle Crenshaw, Mapping the Margins: Intersectionality, Identity Politics, and Violence Against Women of Color, 43 STAN. L. REv. 1241, 1298 (1991) [hereinafter Crenshaw, Mapping the Margins].

83. See Perlin, supra note 14, at 18 (arguing that judges and juries rely on stereotypes in their decision making about the rights of people with mental disabilities).

84. Michael Oliver generally is recognized as having articulated this concept as in the context of disability rights. Michael Oliver, The Politics of Disablement: A Sociological Approach (1990); Kimberle Crenshaw, Race, Reform and Retrenchment: Transformation and Legitimation in Antidiscrimination Law, 101 Harv. L. Rev. 1331 (1988) (race); Kanter, supra note 38, at 420; Adam M. Samaha, What Good Is the Social Model of Disability, 74 U. CHI. L. Rev. 1251, 1251 (2007) [hereinafter Samaha].

85. This concept has been explored extensively by scholars in the context of race, gender, and sexual identity. Cheryl I. Harris, Whiteness as Property, 106 Harv. L. Rev. 1707 (1993) (race); Crenshaw, Mapping the Margins, supra note 82 (race and gender); Jessica Knouse, Intersexuality and the Social Construction of Anatomical Sex, 12 Cardozo J. L. \& Gender 135 (2005) (sexual identity); Rhonda Reaves, "There's No Crying in Baseball": Sports and the Legal and Social Construction of Gender, 4 J. Gender RACE \& Just. 283 (2001); Karen J. Sneddon, Not Your Mother's Will: Gender, Language, and Wills, 98 MArQ. L. Rev. 1535 (2015) (gender); Dylan Vade, Expanding Gender and Expanding the Law: Toward a Social and Legal Conceptualization of Gender that is More Inclusive of Transgender People, 11 Mich. J. Gender \& L. 253 (2005) (gender and sexual identity). 
cial norms, practices, and beliefs; it is both socially produced and socially the particularities of specific bodies. ${ }^{86}$

Obstacles in the built environment present a straightforward illustration of this concept. A student with a physical impairment who uses a mobility device could not easily attend schools not equipped with elevators or ramps. This results in the exclusion of that student from educational opportunities, not because of her inability to learn, but due to her inability to access the classroom. It is not the physiological condition that creates the disability; it is the social failure to provide the means of access that creates the barrier and thus creates the disability.

In the context of mental disability, a person with a physiological or psychological impairment is not inherently mentally disabled. Rather, it is the trait coupled with society's response to that trait that creates the disability. ${ }^{87}$ Thus, society may bar a person with a mental impairment from voting, marrying, or attending school. The law contributes to creating impediments for people with mental disabilities. To be a person with a mental disability can mean, inter alia, not having the capacity to enter into valid, binding contracts. Thus, the law converts mental disability into legal disability. This has significant material consequences for individuals with mental disabilities.

One of the ways in which the mental incapacity doctrine constructs disability identity is by relying on and reifying stereotypic myths or tropes. Satisfying the requirements of the doctrine invites this negative social construction of identity. Contract avoidance requires the person claiming volitional mental incompetency to prove that, at the time of contracting, the other party to the contract knew or should have known of her incompetency. Individuals claiming cognitive incapacity must establish they did not have the ability to understand the nature of the transaction. Under either test, evidence offered by the person with questionable competency or their representative to establish incompetency often includes both lay and expert opinion testimony. ${ }^{88}$

86. Civil Disabilities: Citizenship, Membership, and Belonging 4 (Nancy J. Hirschmann \& Beth Linker eds., 2015).

87. Samaha, supra note 84 .

88. Milton D. Green, Proof of Mental Incompetency and the Unexpressed Major Premise, 53 Yale L.J. 271, 275 (1944). Failure to provide either type of evidence will result in the failure of the party seeking avoidance to overcome the presumption of legal capacity. Sparrow v. Demonico, 960 N.E.2d 296, 298 (Mass. 2012). 
Both lay and expert testimony draw on stereotypic evidence to support the claim of mental incapacity. In doing so, the law gives meaning to the social construct of mental disability. In his essay "An Archive and Anatomy of Disability Myths," Jay Dolmage provides a taxonomy of disability myths, stereotypes, and tropes. ${ }^{89}$ These include the presentation of disability as pathological or as a cause for pity or charity and the universal, inevitable linkage between physical and mental disability—otherwise known as disability drift.

\section{Disability as Pathology}

Disability as pathology undergirds the medical model of disability. Disability is defined as a medical condition or disease without accounting for the social context that may shape the experience of the person with the impairment. The social restrictions imposed on people with intellectual disabilities reflect this pathological concept of disability.

The educational exclusion of students with intellectual disabilities was justified based on the impairment of those students. When Congress enacted the Education for All Handicapped Children's Act $^{90}$ in 1975, it found that almost one-half of the approximate eight million children with disabilities living in the United States received an inadequate education, and one million received no education at all. ${ }^{91}$ Educational institutions conceptualized the intellectual impairment as a disease or medical failing and did not consider how failure to create environments in which students with intellectual disabilities could learn contributed to the students' disabilities. ${ }^{92}$

Disability as a pathology is an interesting concept, particularly when a claimant fails to conform to certain social norms. For example, courts may treat nonconformity with gender roles as evidence of a medically based mental disability. Courts give little, if any,

89. Jay Timothy Dolmage, Disability Rhetoric 31-61 (2014). An earlier cataloguing by Wolf Wolfensberger reflects similar stereotypes. WoLF Wolfensberger, The Principle of Normalization in Human Services 16-24 (1972).

90. Education for All Handicapped Children Act of 1975, P.L. 94-142, 89 Stat. 773 (codified as amended at 20 U.S.C. $\$ \S 1400-1482$ (2017)). The statute has since been renamed the Individuals with Disabilities Education Act.

91. Id. $§ 3,89$ Stat. at 774 .

92. Cf. Mills v. Bd. of Educ., 348 F. Supp. 866 (D.D.C. 1972) (finding the school board had an affirmative duty to provide publicly supported education suited to the needs of each child and discussing how failure to do so precluded "exceptional" children, who could not afford private instruction, from obtaining an education). 
consideration to the social construction of gender and how failure to follow gender norms may be construed by lay jurors and experts alike as evidence of mental disability. ${ }^{93}$

In Associates Financial Services Company of Wisconsin v. Harrell, ${ }^{94}$ a woman used her gender nonconformity as a basis for challenging her mental capacity. Mrs. Harrell and her husband applied to Associates Financial Services Company of Wisconsin ("Associates") for a mortgage loan. Associates approved the loan, and the couple appeared at the office to sign the loan documents. The loan was secured by a mortgage on the couple's property. The Harrells defaulted on the loan payments, and Associates sued to foreclose. After the court granted Associates' motion for summary judgment, Mrs. Harrell challenged the foreclosure on the basis she was mentally incompetent and thus not bound by the loan agreement. ${ }^{95}$ To support her claim of incompetency, she submitted an affidavit in which she was generally described as having a "blank appearance" and as being "disheveled in that her hair, make-up, and clothing are always in disorder, and that she stares inappropriately and is influenced easily." 96 On this basis, Ms. Harrell alleged that Associates knew or should have known of her incompetence. ${ }^{97}$ The court rejected Ms. Harrell's claim of incompetence and upheld summary judgment.

Implicit in the description of Mrs. Harrell's general appearance is the assumption that a "normal" woman would not allow herself to be seen in public with disheveled hair, badly applied makeup, and disordered clothes. Similar statements about the decedent in Allore v. Jewell ${ }^{98}$ can be read not as describing a woman lacking capacity but describing a woman failing to conform to gender norms. The decedent was described as being immodest and dirty, having poor table manners, and using profane and vulgar language. ${ }^{99}$ This testimony was used to prove her lack of mental ca-

93. Commentators have urged courts to be more cognizant of changing social norms and not to draw conclusions based on unconventionality. See Alexander M. Meiklejohn, Contractual and Donative Capacity, 39 CASE W. Res. L. REv. 307, 371 (1988).

94. Assoc. Fin. Servs. Co. v. Harrell, No. 97-0698, 1997 Wisc. App. LEXIS 1401, *1 (WI App. 4 Dec. 4, 1997) (unpublished table decision).

95. $I d$. at $* 6$.

96. Id. at $* 3$.

97. Id.

98. Allore v. Jewell, 94 U.S. 506 (1876).

99. Id. at 508-09. 
pacity; read another way, it describes a woman not conforming to the stereotypical behavior of a woman. ${ }^{100}$

Similarly, in the Matter of Josiah Oakes, ${ }^{101}$ a sixty-seven-yearold man challenged his confinement in an insane asylum. Oakes's sons had involuntarily committed their father primarily to prevent him from marrying the much younger woman to whom he became engaged a few days after the death of his wife. Unsurprisingly, the man was wealthy, and his sons may have been concerned about losing their inheritance. Oakes failed to conform to the expectations of a man of his class and age. The younger woman whom he wanted to marry was said to be of questionable reputation; the sons had her prosecuted for lewdness of character. ${ }^{102}$ As his wife lay dying, Oakes left the house and spent the evening with his soon-tobe fiancé. He failed to show appropriate grief about his wife's death. ${ }^{103}$ The court reviewed these actions and accepted them as evidence of his insanity. ${ }^{104}$

Probably the most infamous case involving allegations of mental incompetence based on failure to adhere to gender norms is Buck v. Bell. ${ }^{105}$ Carrie Buck was committed to the Virginia State Colony for Epileptics and Feeble Minded and had been sterilized while in custody. She later sued the state, arguing the statute allowing for such procedures was unconstitutional. The Supreme Court upheld the statute with Justice Holmes writing his oft-quoted admonition "three generations of imbeciles are enough."106 Extensive research reveals that neither Carrie, her mother, nor Carrie's daughter were imbeciles. Instead, there is significant evidence to suggest Carrie and her mother were labeled imbeciles because of their alleged sexual activity outside of marriage and not because they had intellectual disabilities. ${ }^{107}$ Carrie's failure to adhere to gender norms implicitly supported her characterization as an "imbecile."

100. Conformity with gender norms has been offered as evidence of mental competency. See Bradburn v. McIntosh, 159 F.2d 925, 929 (10th Cir. 1947) ("Nancy [the alleged incompetent person] was a good housekeeper and a good cook; she was clean and dressed neatly.").

101. In re Oakes, 8 Law Rep. 123 (Mass. 1845).

102. Id. at $123-27$.

103. Id. at $126-27$.

104. Id. at 127; see also Ring v. Lawless, 60 N.E. 881, 886 (Ill. 1901) (determining husband's submission to wife's control of property and assets is indication of husband's mental incapacity).

105. Buck v. Bell, 274 U.S. 200 (1927).

106. Id. at 207.

107. Paul A. Lombardo, Three Generations, No Imbeciles: New Light on Buck v. Bell, 60 N.Y.U. L. Rev. 30, 51 (1985). 


\section{People with Disabilities as Objects of Pity}

People with mental disabilities often are portrayed as sad or pathetic in mental incapacity cases. In Farnum v. Silvano, ${ }^{108}$ the testimony about the incompetence of the grantor was as follows:

She would lament not hearing from sisters who were dead. She would wonder where the people upstairs in her house had gone, but there was no upstairs to her house. . . . She became abnormally forgetful. Frequently she locked herself out of her house and broke into it, rather than calling on a neighbor with whom she had left a key.... She hid her cat to protect it from "the cops . . . looking for my cat." 109

From this description, we imagine a woman who was delusional, senile, irrational, and paranoid. Perhaps she was all of these things, but she also was portrayed as an object of pity. This image was compounded by the court's emphasis on the fact that the person to whom she transferred her home was a much younger man, who did yard work for the grantor. The court painted a picture of a pathetic, lonely, older woman infatuated with someone significantly younger to support the conclusion she was mentally incapacitated. The court in Flagstaff Realty, Inc. v. Ned ${ }^{110}$ also portrayed a property seller with a mental disability as a person to be pitied. In holding that the seller was not liable to the plaintiffs for a brokerage commission due to incapacity, the court stated, "We would be short on realism were we to fail to recognize one of life's more tragic vicissitudes,"111 referring to the defendant's mental illness. The court presented the defendant-seller as someone to pity and allowed her to avoid her contractual obligation to pay the commission; the court indicated to hold otherwise would have been unjust. $^{112}$

\section{Disability Drift}

Disability drift, in which the presence of a physical disability is taken as evidence of a mental disability, may occur in mental incapacity cases. Physical disabilities cannot serve as the sole basis for mental incapacity claims. ${ }^{113}$ However, the physical disability en-

108. Farnum v. Silvano, 540 N.E.2d 202 (Mass. App. Ct. 1989).

109. Id. at 203.

110. Flagstaff Realty v. Ned, 544 A.2d 385 (N.J. Super. Ct. App. Div. 1987).

111. Id. at 388.

112. Id. at $388-89$.

113. Feinberg v. Leach, 243 F.2d 64, 67-68 (5th Cir. 1957); Page v. Prudential Life Ins. Co., 120 P.2d 527, 531 (Wash. 1942); Strong v. Holden, 697 S.E.2d 189, 191 (Ga. 2010); 17 C.J.S. Contracts § 173 (1963). 
hances the incapacity claim when coupled with evidence of mental disability. In the context of contracts, the quintessential example of disability drift involves individuals who are deaf.

Historically, the law provided that people who were deaf and mute were presumptively "idiots" and thus lacked the capacity to enter into contracts as a matter of law. ${ }^{114}$ The assumption was the physical inability to hear and speak indicated a concomitant mental disability. Courts equated the physical inability to hear with mental disability and voided contracts entered into by people who were deaf. Thus, people who were deaf were legally prohibited from entering into contracts. Indeed, in the 1800 s, deaf individuals could be adjudicated insane and sent to live in institutions for the mentally ill based solely on their inability to hear and speak. ${ }^{115}$ Eventually, the doctrine evolved and created a rebuttable presumption of incompetency ${ }^{116}$ which itself gave way to the presumption of competency granted to hearing people. ${ }^{117}$ Despite the formal elimination of the presumption of mental incapacity, and even as scientific research revealed the fallacy of equating deafness to mental disability, the law was hesitant to completely disregard deafness in cases involving the enforcement of contracts. ${ }^{118}$

The court engaged in disability drift in Fewkes v. Borah. ${ }^{119}$ There, the court set aside an oil and gas lease based on mental incapacity in which the only evidence of incapacity was that plaintiff could neither hear nor speak. Culley v. Jones ${ }^{120}$ is similar in that a couple, neither of whom could hear or speak, sought to avoid a contract to sell their land based on fraud. The court invalidated the contract, noting that the couple were deaf-mutes and of feeble intellect and thus without the capacity to understand the transaction. ${ }^{121}$ The plaintiff in Lang v. Derr ${ }^{122}$ sought to invalidate a contract that conveyed her interest in her father's estate based on

114. See Barnett v. Barnett, 54 N.C. 221, 222 (1854) ("In the earlier history of the law, a person who was born deaf and dumb, was considered to be an idiot."); GAW, supra note 1, at 82; MYERs, supra note 25, at 50.

115. GAw, supra note 1, at 79.

116. Brower v. Fisher, 4 Johns. Ch. 441, 444 (N.Y. Ch. 1820); Oliver v. Berry, 53 Me. 206, 206 (1865); In re Alleged Lunacy of Perrine, 5 A. 579, 580 (N.J. Ch. 1886); Alexier v. Matzke, 115 N.W. 251, 252 (Mich. 1908).

117. Barnett, 54 N.C. at 225.

118. Myers, supra note 25, at 53; see also Carbine v. McCoy, 11 S.E. 651,652 (Ga. 1890); Selenak v. Selenak, 150 Ill. App. 399, 401 (1909); Larson v. Western Underwriters, Inc., 87 N.W.2d 883, 885-87 (S.D. 1958).

119. Fewkes v. Borah, 35 N.E.2d 69 (Ill. 1941).

120. Culley v. Jones, 73 N.E. 94 (Ind. 1905).

121. Id. at $96-97$.

122. Lang v. Derr, 569 S.E.2d 778 (W. Va. 2002). 
unconscionability. In invalidating the conveyance, the court noted the plaintiff was deaf and did not enter "the contract with a full understanding of its consequences."123 The language used by the appellate court is essentially the test used to measure contractual capacity: was the plaintiff able to understand the consequences of the transaction? The court was implicitly arguing that the appellant did not have the capacity to enter into the contract and based its decision, in part, on her inability to hear.

Deafness can play a role in invalidating a contract even if mental incapacity is not specifically pled. In Wendell $v$. Payne, ${ }^{124}$ a profoundly deaf man was seriously injured when a train struck him. As he lay in the hospital recovering from his injuries, representatives from the railroad company approached him to settle any claims he might make against the company. They encouraged him to sign a release of claims in exchange for the company's agreement to pay for all his medical bills. Pursuant to the release, the plaintiff waived his right to recover against the railroad company for all of his injuries, pain, suffering, and lost wages. Ultimately, the plaintiff challenged the validity of the release. The court held that the release was invalid, relying in part on "his infirmity of hearing and speech." 125

The Renchard case set forth at the beginning of this essay is a recent case that exemplifies disability drift and the court's hesitancy to disregard the plaintiff's deafness in assessing his claim of mental incapacity. In challenging the repossession and sale of his yacht, Mr. Renchard alleged that he did not have the mental capacity to understand the agreements he made with the defendant-seller/ lender. Mr. Renchard asserted he was deaf and could not read or write sophisticated words. ${ }^{126}$ In allowing the plaintiff's case to proceed, the court indicated Mr. Renchard's physical disability may have impacted his ability to understand the nature of the transactions he had entered into. ${ }^{127}$ The only physical disability the plaintiff identified was his deafness; the court did not explain why the plaintiff's deafness should be relevant to any mental disability the plaintiff may have had. That the plaintiff was purchasing a yacht, had a trust fund, had figured out how to liquidate that trust fund, and was able to determine how to purchase a yacht worth $\$ 1.4$ mil-

123. Id. at 782.

124. Wendell v. Payne, 109 S.E. 734 (W. Va. 1921).

125. Id. at 738 .

126. Renchard v. Prince William Marine Sales, Inc., 87 F. Supp. 3d 271, 280-81 (D.D.C. 2015).

127. Id. at 281. 
lion did not persuade the court that the plaintiff had the mental capacity to enter into contracts concerning the care and maintenance of the yacht. By inexplicably connecting deafness with mental disability, the court deployed the myth that the existence of a physical disability lends support to a claim of mental disability.

The law of mental incapacity helped transform deafness from a physical condition to a mental disability; in turn, this led to the designation of deaf people as legally disabled. While contracts entered into by deaf people are no longer void or voidable, deafness continues to be linked with mental disability when mental incapacity is pled as a basis for avoiding a contract. ${ }^{128}$ This link is symbolically important even if the doctrine is pled unsuccessfully.

In all of these mental incapacity cases invoking disability myths and stereotypes, lay people or medical experts present the testimonial proof. Somewhat ironically, courts are more likely to give lay testimony more weight than the testimony of medical experts on the topic of mental incompetence. ${ }^{129}$ One court argued, "[T]he requisite proof regarding mental capacity is within the common knowledge and experience of lay persons[,] and therefore, expert testimony is not required." 130 There has been significant skepticism, and perhaps even fear, that medical testimony about mental illness and mental disability is unreliable and speculative. ${ }^{131}$ Some of that skepticism arises from the field of psychiatry's relative infancy and its application to the legal field. ${ }^{132}$ Additionally, although the opinions of medical experts ideally are based on data, this data may not be sufficient to support an objective opinion con-

128. See, e.g., Lieb v. Royal Caribbean Cruise Line, Inc., 645 F. Supp. 232, 235 (S.D.N.Y. 1986); Panco v. Rogers, 87 A.2d 770, 773-74 (N.J. Super. Ct. Ch. Div. 1952).

129. See Heights Realty, Ltd. v. Phillips, 749 P.2d 77, 80 (N.M. 1988); Faber v. Sweet Style Mfg. Corp., 242 N.Y.S.2d 763, 768-69 (N.Y. Sup. Ct. 1963); Brucken et al., supra note 17, at 1041 ("The opinions of lay persons present at the transaction as to a person's mental ability are often relied on heavily by the courts."); Green, Proof of Mental Incompetency, supra note 88, at 284. But see Sparrow v. Demonico, 960 N.E.2d 296, 304 (Mass. 2012) (concluding that "medical evidence is necessary to establish that a person lacked the capacity to contract due to the existence of a mental condition").

130. Decker v. Decker, 192 S.W.3d 648, 652 (Tex. App. 2006).

131. See George J. Alexander \& Thomas S. Szasz, From Contract to Status via Psychiatry, 13 Santa Clara Lawyer 837, 545-46 (1972); Green, Proof of Mental Incompetency, supra note 88, at 284-86; Meiklejohn, supra note 93, at 309. Even those commentators who have raised the concern about the overreliance on medical testimony fail to consider the negative consequences of the overreliance on lay testimony from the perspective of people with disabilities.

132. See Brakel ET AL., supra note 1, at 721. 
cerning the person's capacity when the contract was formed. ${ }^{133}$ Thus, in the view of one court ". . . in the great majority of cases psychiatrists of equal qualification and experience will reach diametrically opposed conclusions on the same behavioral evidence. The courts have, therefore, tended to give less weight to expert testimony than to objective behavioral evidence."134 Lay testimony, then, is critical in persuading the fact finder of a person's incompetency. ${ }^{135}$

That the above-quoted court considered lay testimony to be "objective" is troubling, as is the general practice of courts favoring lay over expert testimony. ${ }^{136}$ The judgments and opinions offered by friends, family, neighbors, and colleagues are not formed in a vacuum. Ideas about people with mental disabilities are influenced and shaped by cultural forces: the media, education, politics, religion, and the law all contribute to the conceptualization of mentally ill and disabled people. Lay testimony is neither neutral nor objective; because it operates within a social context, lay testimony can be subject to stereotypic concepts of people who are mentally ill or mentally disabled. ${ }^{137}$

The tests used to measure mental incapacity socially construct disability. The requirement that the competent party should have known essentially demands that the competent party draw conclusions about the person with a mental disability based on the dis-

133. Butler v. Harrison, 578 A.2d 1098, 1100, 1101 (D.C. 1990); Green, Proof, supra note 88 , at 284 .

134. Faber, 242 N.Y.S.2d at 768.

135. The reliance on lay testimony to establish incompetency is a long-established tradition in Anglo-American law. See BRAKel ET AL., supra note 1, at 11 (describing that the method of determining the mental status of someone with questionable competency in the early 1600s in England was through a petition to the court which sought a determination of competency from a jury of twelve men).

136. I note here that relying on medical expertise is not without its own risks. In assessing capacity in the guardianship context, statutes require that evidence from medical experts be submitted to the court as to a person's capacity or lack thereof. See Beyond Guardianship, supra note 18, at 77. Much greater deference is given to medical expertise than to lay opinions in the context of guardianship proceedings. However, the determinations made by such medical experts can be extremely problematic. See id. at 77-83.

137. Early in the history of the development of the field of psychiatry, this concern about reliance on extrinsic evidence was expressed. In 1862, an article appeared in The British Medical Journal expressing skepticism about the use of extrinsic evidence to establish insanity. Can the Man Be Morally Insane in Whom Is Found No Insane Delusion?, 1 BRIT. MED. J. 38, 38-39 (1862); see also Green, Proof of Mental Incompetency, supra note 88, at 275, 284; Rein, Clients with Destructive and Socially Harmful Choices-What's an Attorney to Do?, supra note 18, at 1119 . 
abled person's outward conduct and appearance. ${ }^{138}$ Similarly, the requirement of establishing the person did not understand the transaction demands the same kind of "parade of horribles."139 Recall that it is the person with a mental disability herself, or more likely, the person's informal or formal representative, that must rebut the presumption of mental competency. ${ }^{140}$ Thus, the person with a mental disability or her guardian is called on to use stereotypes about mental disability to establish incompetency. Fact finders in court are then empowered to decide whether the evidence of mental disability comports with their lay understanding of disability. ${ }^{141}$ This is the very kind of judgment the ADA and disability rights advocates are trying to eliminate. It is time to rain on the parade of horribles.

138. The court in McGovern states this expressly: “. . . a person's mental capacity is best determined by his spoken words and his conduct, and . . . the testimony of persons who observed such conduct on the date in question outranks testimony as to observations made prior to and subsequent to that date." McGovern, 517 A.2d at 384.

139. Here is one description of a grantor whose conveyance was challenged based on mental incapacity:

Thus, some of the witnesses speak of the deceased as having low and filthy habits; of her being so imperfectly clad at times to expose immodestly portions of her person; of her eating with her fingers, and having vermin on her body. Some of them testify to her believing in dreams, and her imagining she could see ghosts and spirits around her room, and her claiming to talk with them; to her being incoherent in her conversation, passing suddenly and without cause from one subject to another; to her using vulgar and profane language; to her making immodest gestures; to her talking strangely, and making singular motions and gestures in her neighbors' houses and in the streets.

Allore v. Jewell, 94 U.S. 508-509 (1876); Flagstaff Realty, Inc. v. Ned, 544 A.2d 385, 386 (N.J. Super. Ct. App. Div. 1987) ("Cora . . . has been diagnosed as a paranoid schizophrenic who suffers from delusions of persecution, hallucinations and suicidal thoughts ... Cora was extremely unstable ... she was unable to eat or bathe and was virtually bedridden . . . "psychotic and incoherent." "); In re Estate of Minton, No. 13-12-00026-CV, 2014 WL 354527, at *2-4 (Tex. App. Jan. 30, 2014).

140. HunTer, supra note 45, § 2:14.

141. See Ortelere v. Teachers' Retirement Bd., 250 N.E.2d 450, 468 (N.Y. 1969) (Jasen, J., dissenting) ("In the final analysis, the lay jury will infer the state of the party's mind from his observed behavior as indicated by the evidence presented at trial. Each juror instinctively judges what is normal and what is abnormal conduct from his own experience ..." (emphasis added)); Green, Proof of Mental Incompetency, supra note 88, at 283 ("Courts assume that anyone is capable of forming an opinion as to the mental competency of another and that no special qualifications are needed, provided that the opinion is based upon facts observed."); HunTer, supra note 45, § 2:14. 


\section{B. Deconstructing Disability: The DRM and the ADA}

Not only do the tests for measuring mental incapacity demean individuals with disabilities, but they also risk violating the ADA. Disability studies scholars and disability rights advocates appreciate the role the law can play and has played in socially constructing disability. The mental incapacity doctrine obviously predates these movements and thus does not to take into consideration the concerns articulated by and about people with disabilities. The law does not function in a vacuum. Therefore, it is appropriate to modify the mental incapacity doctrine in light of the DRM's competing values.

The Disability Rights Movement involves several projects, ${ }^{142}$ the goals of which conflict with or are undermined by the mental incapacity doctrine. One project is elimination of stereotypes and the negative, material consequences they have on the lives of people with disabilities. ${ }^{143}$ In enacting the ADA and its amendments, Congress expressly found that "people with physical or mental disabilities are frequently precluded from [fully participating in society] . . . because of prejudice, antiquated attitudes, or the failure to remove societal and institutional barriers."144 Congress continued, noting the "continuing existence of unfair and unnecessary discrimination and prejudice denies people with disabilities the opportunity to compete on an equal basis and to pursue those opportunities for which our free society is justifiably famous." 145 The definition of disability in the ADA, that includes any person perceived as having a disability, was designed expressly to take into account perceptions and misconceptions of disability. The legislative history of the 2008 ADA Amendments Act reveals this congressional intention: "[ $\mathrm{t}] \mathrm{his}$ section of the definition of disability [referring to the 'regarded as' prong of the definition] was meant to express our understanding that unfounded concerns, mistaken beliefs, fears, myths, or prejudice about disabilities are often just as disabling as actual im-

142. This essay adopts the language used by Professor Samuel Bagenstos to describe the various projects of the Disability Rights Movement. See SAmuel Bagenstos, Law and the Contradictions of the Disability Rights MoveMENT 2-3, 6-33 (2009).

143. Samuel Bagenstos, Subordination, Stigma and Disability, 86 VA. L. REv. 397, 433 (2000); see also Robert L. Burgdorf Jr., The Americans with Disabilities Act: Analysis and Implications of a Second-Generation Civil Rights Statute, 26 Harv. C.R.-C.L. L. Rev. 413, 427-28 (1991).

144. 42 U.S.C. $\S 12101(\mathrm{a})(2)$ (2008).

145. Id. § 12101(a)(8). 
pairments."146 As one disability rights lawyer states, the goal of the "regarded as" impaired language was to ensure that "prejudice, stereotypes, and neglect based on impairments are now prohibited to the same extent as they would be in the case of other protected characteristics."147

Even before the passage of the ADA, courts recognized people with disabilities were subjected to certain myths and prejudice. In the oft-cited U.S. Supreme Court case School Board of Nassau County, Florida. v. Arline, ${ }^{148}$ the Court discussed the definition of disability within the Rehabilitation Act of 1973-the ADA directly copied this definition. In finding that the definition of "handicapped person" included someone diagnosed with tuberculosis, the Court argued that Congress intended the definition to be broad to acknowledge "that society's accumulated myths and fears about disability and disease are as handicapping as are the physical limitations that flow from the actual impairment."149

The concern about eliminating stereotypes encompasses the desire to eliminate both the stigma associated with mental disability and the discrimination against and subordination of people with disabilities. The subordinate status of people with disabilities in American society is reflected in statistical surveys; what the statistics reveal is disheartening. According to the U.S. Census Bureau, in 2015 , only 34.4 percent of people with a disability between ages 21 and 64 were employed. ${ }^{150}$ In 2014, fewer than 17 percent of adults with a disability age 25 or older had a bachelor's degree. ${ }^{151}$ And in 2015, the median annual income of households that include working-age people with disabilities was $\$ 41,600 .{ }^{152}$ These statistics illustrate the ongoing challenge faced by people with disabilities:

146. 154 Cong. Rec. S8842 (daily ed. Sept. 16, 2008) (statement of Senate Managers); accord H.R. REP. No. 110-730, pt. 2, at 17 (2008).

147. Kevin Barry, Toward Universalism: What the ADA Amendments Act of 2008 Can and Can't Do for Disability Rights, 31 Berkeley J. EMP. \& LAB. L. 203, 279 (2010).

148. Sch. Bd. of Nassau Cty. v. Arline, 480 U.S. 273 (1987).

149. Id. at 284 .

150. C. Lee W. Erickson \& S. von Schrader, Disability Statistics from the American Community Survey (ACS), Cornell University Yang-Tan Inst. (click on "find disability statistics" then "employment rate" and select ages 12-64 from the "age" drop down menu and 2015 in the "year" drop down menu).

151. See Bureau of Labor Stat., U.S. Dep't of Labor, People with a Disability Less Likely to Have Completed a Bachelor's Degree, TED: THE ECONOMICS DAILY (July 20, 2015) https://bit.ly/2mJpwih [https://perma.cc/C34C-LLDF].

152. C. Lee W. Erickson \& S. von Schrader, Disability Statistics from the American Community Survey (ACS), Cornell University Yang-Tan Inst. (click on "find disability statistics" then "annual household income" and select 2015 in the "year" drop down menu). 
inclusion. The stereotypes and the prejudice contribute to the exclusion of those with disabilities. ${ }^{153}$ Bias limits their life opportunities, such as employment, housing, and education. ${ }^{154}$ Their rights to marry, procreate, vote, and enter into contracts also are negatively affected by stereotypes and prejudice. Indeed, no aspect of their lives is untouched by prejudice.

It is the pervasiveness of harm that triggered disability rights activists to take action. In No Pity, Joseph Shapiro chronicles the way in which the Disability Rights Movement has attacked stereotyping and revealed its oppressiveness:

Disabled people have become sensitized to depictions of disability in popular culture, religion and history. There they find constant descriptions of a disabled person's proper role as either an object of pity or a source of inspiration. These images are internalized by disabled and nondisabled people alike and build social stereotypes, create artificial limitations, and contribute to discrimination. ${ }^{155}$

Shapiro makes a compelling case for the way in which popular culture, religion, and history contribute significantly to the stereotypes about individuals with mental disabilities. ${ }^{156}$ From Shakespeare's King Richard III to modern horror films, individuals with mental disabilities are portrayed as evil and murderous. ${ }^{157}$ They are to be feared and, when necessary, segregated from society. ${ }^{158}$ There is even a study that hypothesized these stereotypes and the related stigma may result in the disparate treatment of people with psychiatric disabilities under Title I of the ADA. ${ }^{159}$ This study

153. See Jacobus tenBroek \& Floyd W. Matson, The Disabled and the Law of Welfare, 54 CAL. L. REv. 809, 814-15 (1966).

154. See generally Douglas Kruse et al., Why Do Workers with Disabilities Earn Less? Occupational Job Requirements and Disability Discrimination, 56 BRIT. J. OF InDUs. REL. 798 (2017) (demonstrating that lower earnings by people with disabilities may be the result of discrimination).

155. Joseph P. Shapiro, No Pity 30 (1993).

156. Id. at 30-31; see also Alan Gartner, Images of the Disabled, DisaBling Images (Alan Gartner \& Tom Joe, eds., 1987); Paul K. Longmore, Screening Stereotypes: Images of Disabled People in Television and Motion Pictures, in IMAges of THE Disabled 65 (Alan Gartner \& Tom Joe, eds., 1987); Rosemarie Garland-Thomson, Disability and Representation,120 PMLA 522, 522-23 (2005); Paul K. Longmore, The Cultural Framing of Disability: Telethons as a Case Study, 120 PMLA 502, 505-08 (2005).

157. Frank Bowe, Handicapping America 108-11 (1978).

158. See U.S. Comm'n on C.R., Accommodating the Spectrum of Individual AbiLities, 22-26 (1983).

159. See generally Jeffrey Swanson et al., Justice Disparities: Does the ADA Enforcement System Treat People with Psychiatric Disabilities Fairly? 66 MD. L. REV. 94 (2006) (conducting a study that "describes and compares the characteris- 
found that people with psychiatric disabilities have significantly worse outcomes in employment discrimination lawsuits than their neurotypical counterparts; one possible explanation for this disparate treatment is the stigma associated with mental disabilities. ${ }^{160}$

Given the DRM's values and the goal of deconstructing disability reflected in the ADA, it is appropriate to restrict the use of the mental incapacity doctrine to cases in which the claimant was previously adjudicated incompetent. At least one court has indirectly expressed support for this approach, albeit for reasons other than objecting to stereotypes about people with a mental disability:

Financial institutions are not equipped to assess mental conditions of their customers and should not be expected to do so. The line between the idiosyncratic person and a mildly or even moderately mentally disturbed person can easily become blurred. An idiosyncratic person is surely entitled to free access to a bank's services, and this freedom would be compromised to any extent such persons could escape responsibility for their commercial transactions. Utter chaos would attend a rule that would require a bank to conduct its customer relations on the basis of its lay assessment of the customer's mental condition. ${ }^{161}$

The dicta in this opinion unintentionally reinforces the position taken by Congress when enacting the ADA. It reveals discomfort with the idea that an entity contracting business with a person can and should be responsible for diagnosing the mental capacity of a potential client. The ADA includes in its definition of disability a person "regarded as having a disability." One of the goals of including this language is to attack specifically the kinds of assumptions made by lay people about those with disabilities. This prohibition inherently challenges the idea that lay people are qualified and should be permitted to draw conclusions about a person's mental abilities based on the limited observations of that person. The court expressed its reservations about the appropriateness of imposing this responsibility on a bank.

However, the law of mental incapacity seemingly demands that covered entities engage in the very behavior that disability discrimination law is trying to prohibit. It may very well be that jurors approach the question of mental incompetence by using their own experiential yardsticks. However, misconceptions, inaccurate as-

tics of people with psychiatric and non-psychiatric disabilities who filed for employment discrimination lawsuits under Title I of the ADA").

160. Id. at $133-34$.

161. Putensen v. Hawkeye Bank of Clay Cnty., 564 N.W.2d 404, 408 (Iowa 1997). 
sumptions, and false information about disabilities warp these yardsticks. Reducing the cases in which stereotypic tropes and disability myths can be used will help to deconstruct-rather than construct and reinforce-the negative connotations associated with mental disability. Limiting the mental incapacity doctrine to instances in which one party was adjudicated incompetent will help accomplish this goal.

\section{Mental Incapacity Doctrine, Exclusion, and Integration}

The mental incapacity doctrine can undermine the DRM and ADA goal of encouraging and enabling people with mental disabilities to fully participate in society. Providers of goods and services subject to both the law of mental incapacity and the ADA face a dilemma: they may be reluctant to enter into contracts with people who are or whom they perceive to be disabled. ${ }^{162}$ This reluctance can severely deprive people with disabilities from living a full, rich life in accordance with their wishes and desires. The ability to enter into contracts is inextricably tied to the ability to participate fully in society. Limiting the mental incapacity doctrine prioritizes the value of full participation and integration of those with mental disabilities.

Integration is a core value of the DRM and the ADA. ${ }^{163}$ Professor Jacobus tenBroek, a preeminent disability rights scholar, equated integration with the concept of "the right to live in the world":

The right to live in the world consists in part of the right to live out of it. The blind, the deaf, the lame, and the otherwise physically disabled, have ... not only the right to rent a home or an apartment, public or private housing, but the right to live in it; the right to determine their living arrangements, the conduct of their lives; the right to select their mates, raise their families, and receive due protection in the safe and secure exercise of these rights. ... But the world in which the disabled, too, have a right to live is also ... in the schools and colleges ... in the factories, shops and offices, in short, in all the places where men are, go,

162. Cf. Edward D. Jones \& Co. v. Fletcher, 975 S.W.2d 539, 545 (Tex. 1998) (arguing in dicta that "imposing liability on service providers for dealing with elderly persons discourages such dealings, thereby impairing the elderly's access to services they would unquestionably have if younger. This contravenes sound policy").

163. See Jacobus tenBroek, The Right to Live in the World: The Disabled in the Law of Torts, 54 CAL. L. Rev. 841, 843-47 (1966); see also Allison CAREY, On the Margins of Citizenship (2009); Charlton, supra note 38; Shapiro, supra note 155 . 
live, work, and play. The policy of the law . . should be . . to permit, enable and encourage men to be a part of their communities to the full extent of their physical capacities. ${ }^{164}$

Although Professor tenBroek was concerned primarily about people with physical disabilities, the sentiments expressed apply with the same force to people with mental disabilities.

Integration became a core value of the DRM largely because of America's long history of the physically and socially constructed exclusion of people with mental disabilities. In colonial times, when Europeans were immigrating to and settling in America, survival was their uppermost concern. ${ }^{165}$ Immigrants with disabilities were deemed burdensome and unproductive, and laws in the original 13 colonies excluded people with mental, physical, or emotional disabilities. $^{166}$ For those with mental disabilities, the state made decisions about the extent they could participate in certain civil aspects of society. ${ }^{167}$ Many states proscribed the civic and social participation of people deemed intellectually incompetent; states prohibited them from voting, entering into contracts, marrying, and serving on juries. ${ }^{168}$

The American Industrial Revolution of the mid-1800s initiated a shift in the care of, social integration of, and control over people with mental disabilities. With the industrialization of America came the increased emphasis on productivity and the obligation of citizens to contribute economically to society. ${ }^{169}$ For people with intellectual and developmental disabilities, education became the

164. tenBroek, The Right to Live in the World, supra note 163, at 918.

165. Deutsch, supra note 37, at 39 ("The settlements were generally sparse and scattered, populated for the most part by an impecunious people who lived on the ragged edge of existence, engaged in constant struggle to wrench a bare living from the soil.").

166. See, e.g., An Act Directing the Admission of Town Inhabitants, Acts and Resolves Passed by the Gen. Court of Mass. ch. 23, § 2 (1700-1701); U.S. CoMm'N ON C.R., supra note 158, at 18.

167. The period under discussion was antebellum America; consequently, the discussion is limited to white people with disabilities. For a fascinating look at the treatment and status of slaves with disabilities, see generally Dea Boster, African American Slavery and Disability (2012); Dea Boster, "Unfit for Ordinary Purposes": Disability, Slaves, and Decision Making in the Antebellum American South, in Disability Histories, ch. 10, 201 (Susan Burch \& Michael Rembis, eds., 2014) (indicating slaves with disabilities were rendered unfit, defective, and, in some instances, completely valueless); Anthony R. Chase, Race, Culture, and Contract Law: From the Cottonfield to the Courtroom, 28 ConN. L. REv. 1, 19-20 (1995); see also Batten v. Faulk, 49 N.C. 233, 233 (N.C. 1856) ("[A] slave can make no contract. ... He has no legal capacity to make a contract. He has no legal mind.").

168. CAREY, supra note 163, at 2.

169. Philip M. Ferguson, Abandoned to Their Fate 7-8 (1994). 
means by which they were converted from consumers to producers. Schools for people with mental disabilities developed to transform these individuals into productive members of society. ${ }^{170}$ Initially, these schools were private, but their founders were able to convince various state legislatures that public funds should be allocated for their administration. ${ }^{171}$ This led to the social segregation of people with intellectual disabilities thus beginning the shift from community integration. The segregation was justified as an effort to provide protection for those with mental disabilities. ${ }^{172}$

In the latter half of nineteenth century America, schools for people with mental disabilities, which were directed toward the training and the social reintegration of "idiots," gradually morphed into custodial institutions. Persons with disabilities confined within these institutions became permanent residents rather than students in pursuit of educational training. ${ }^{173}$ The state became the primary caregiver and decision-maker for people confined to these institutions. The shift away from integration to permanent segregation and exclusion was motivated by and in response to Social Darwinism and its progeny, the eugenics movement. ${ }^{174}$ The justification for this isolation shifted from protecting individuals with disabilities from society to protecting society from those with disabilities. ${ }^{175}$

The popularity of the institutionalization of people with mental disabilities continued well into the mid-1960s. ${ }^{176}$ At this point, several forces gathered to push toward deinstitutionalization. First, civil rights movements for African Americans, women, Latinx, and eventually, the LGBQ community, gained momentum during the 1960s and 70s. ${ }^{177}$ Additionally, parents of children with disabilities initiated a revolution against institutionalization and began demanding different treatment for their children. ${ }^{178}$ People with disabilities also began to advocate for themselves. ${ }^{179}$ The idea that

170. James Trent, Inventing the Feeble Mind: A History of Intellectual Disability in the United States 8-11 (2017) (citing to Samuel Gridley Howe's 1848 Report to the Massachusetts Legislature at 23-24).

171. Id. at $10-11$.

172. U.S. Comm'N on C.R., supra note 158, at 19.

173. Id.; Trent, supra note 170 , at 24-30.

174. U.S. Comm'N ON C.R., supra note 158, at 19-20; Deutsch, supra note 37, at 354-86; Robert Whitaker, Mad in America 41-72 (2002).

175. See U.S. COMM'N ON C.R., supra note 158, at 19-20; CAREY, supra note 163, at 83-104; Deutsch, supra note 37, at 350-53.

176. BRAKEL ET AL., supra note 1 , at 17.

177. See CAREY, supra note 163 , at 136-37.

178. See id. at 106-32.

179. Charlton, supra note 38, at 113-26; Independent Living for PhysiCally Disabled People 8, 11-12, (Nancy M. Crewe \& Irving Kenneth Zola, eds., 
people with disabilities should be segregated either for their own protection or because they were a menace to society subsided; institutionalization as the preferred method of managing people with mental disabilities was denounced. Court cases such as Pennsylvania Association for Retarded Children v. the Commonwealth of Pennsylvania, ${ }^{180}$ Halderman v. Pennhurst State School and Hospital, ${ }^{181}$ and ultimately, City of Clebourne v. Clebourne Living Center ${ }^{182}$ all supported, to varying degrees, the end of the segregation of people with mental disabilities. Mental health professionals, advocates, and parents argued that people with mental disabilities should be removed from institutions and cared for either by their families or in a community setting. ${ }^{183}$ Public policy shifted from exclusion to inclusion. ${ }^{184}$

Federal legislation incorporated the value of inclusion, at least facially, if not in practice. The ADA followed several federal statutes designed to effectuate the public policy of integrating people with disabilities. ${ }^{185}$ However, courts and governmental agencies were not diligent in enforcing the statutes. ${ }^{186}$ Disability rights advocates attempted to remedy this by pushing for the enactment of the ADA. The hope was for Congress finally to enact a statute and subsequent regulations that would be a powerful tool to end the discrimination against and segregation of people with disabilities.

1983); Shapiro, supra note 155 , at 117 Duane F. Stroman, The Disability Rights Movement (2003).

180. Pa. Ass'n for Retarded Children v. Pennsylvania, 343 F. Supp. 279 (E.D. Pa. 1972).

181. Halderman v. Pennhurst State Sch. \& Hosp., 446 F. Supp. 1295 (E.D. Pa. 1978), aff'd in part, rev'd in part, 612 F.2d 84 (3d Cir. 1979).

182. City of Cleburne v. Cleburne Living Ctr., 473 U.S. 432 (1985).

183. BRAKel ET AL., supra note 1, at 17.

184. One additional factor motivating deinstitutionalization was the desire by governments, both state and federal, to reduce state spending on institutions for people with mental disabilities. President Ronald Reagan led the charge to defund such institutions, not for policy reasons but rather to save money. Unfortunately, those people with mental disabilities who no longer are committed to large state sponsored institutions have been neglected by federal, state, and local governmental and society at large. Michael Perlin has written a compelling article on this topic. See generally Michael L. Perlin, Competency, Deinstitutionalization, and Homelessness: A Story of Marginalization, 28 Hous. L. REv. 63 (1991).

185. These statutes include the Architectural Barriers Act, 42 U.S.C.A. $\S \S 4151-4157$; the Rehabilitation Act of 1973, 29 U.S.C. $\S \S 791-796$; and the Education for All Handicapped Children Act, 20 U.S.C. \$§ 1400-1482 (now known as the Individuals with Disabilities Education Act).

186. See Timothy M. Cook, The Americans with Disabilities Act: The Move to Integration, 64 Temp. L. Rev. 393, 399-415 (1991); Bowe, supra note 157, at $31-34$. 
The legislative history of the ADA and the statutory language reveal that discrimination, isolation, and segregation were harms to be remedied by the statute. Congress expressly found that "historically, society has tended to isolate and segregate individuals with disabilities," 187 noting "individuals with disabilities continually encounter various forms of discrimination, including outright intentional exclusion." 188 Congress further stated "the Nation's proper goals regarding individuals with disabilities are to assure equality of opportunity, full participation, independent living, and economic self-sufficiency for such individuals." 189 Title III of the ADA specifically provides that "goods, services, facilities, privileges, advantages, and accommodations shall be afforded to an individual with a disability in the most integrated setting appropriate to the needs of the individual."190 These findings made the goals of the statute unambiguously clear. The statute itself specifies that entering into contracts is a strategy that can be used to ensure the full participation and inclusion of those with disabilities. The ADA provides that the refusal of covered entities, including a broad swath of private actors, to enter into contracts with the disabled is an act of discrimination. ${ }^{191}$

Societal integration is a policy goal embraced by the DRM and reflected in the ADA. While there are endless strategies for achieving this integration, entering into contracts plays a significant role in accomplishing integration. The mental incapacity doctrine counteracts this goal, as it creates uncertainty for those who may contract with people with mental disabilities and thus discourages individuals from doing so. This reluctancy to contract challenges the goal of integration. Narrowing the scope of the mental incapacity doctrine reduces the uncertainty of enforcement and encourages people to engage contractually with people with mental disabilities.

Reluctance to enter into a contract occurred in Dudley v. Hannaford Brothers Company, ${ }^{192}$ in which the defendant refused to enter into a contract with a person perceived as having a disability. The plaintiff sought to purchase alcohol at a Shop'n Save grocery store. The defendant's employees refused to tender the sale based on the belief the plaintiff was intoxicated. The plaintiff had substantial mental and physical disabilities resulting from injuries sus-

187. 42 U.S.C. $\S 12101(a)(2)$ (2012).

188. Id. § 12101(a)(5).

189. Id. § 12101(a)(7).

190. Id. § 12182(b)(1)(B).

191. Id. § 12182(b)(1)(A)(i).

192. Dudley v. Hannaford Bros. Co., 146 F. Supp. 2d 82 (D. Me. 2001). 
tained in an automobile accident. Despite the plaintiff's attempt to explain that he suffered from a disability and was not intoxicated, the defendant's employees refused to tender the sale. Plaintiff sued, alleging discrimination under Title III of the ADA. The court determined the plaintiff stated a cause of action under the ADA. ${ }^{193}$

A more recent case illustrates a vendor's reluctance to enter into a contract with someone perceived as having a mental disability. A woman in her 80s was living independently and fell behind on her rent. The landlord agreed to arrange a payment plan but only if the tenant was assigned a court appointed guardian to manage her finances. ${ }^{194}$ She reluctantly agreed to this appointment to avoid being evicted. ${ }^{195}$ Although the woman did not bring a claim for discrimination under the ADA, this case illustrates the landlord's reluctance to enter into a contract with someone he perceived to have a mental disability.

In Renchard, the plaintiff desired to purchase a yacht and arrange for its care and maintenance. To do so, Mr. Renchard needed to enter into contracts with the defendant, Prince William Sales, Inc. Based on lack of his own capacity, the plaintiff called the enforceability of those contracts into question. The court's willingness to allow the plaintiff to avoid these contracts could have significant repercussions. If the defendant subsequently had sought advice from counsel on whether to enter into a transaction with someone with disabilities, like the plaintiff in Renchard, prudent counsel would advise the lender about the possibility of avoidance and rescission based on the claim of mental incapacity. Counsel also would be obligated to point out that the lender was subject to the ADA. At that point, the lender would have to weigh the risk of avoidance and rescission against the risk of a discrimination claim under the ADA. The entity may simply decline to enter into contract with a person whom it suspects may have a mental disability. As noted by the National Council on Disability, “... doctors, landlords, bankers, and others may nonetheless refuse to treat, rent to,

\section{Id. at 86 .}

194. Theresa Vargas, This 87-year-old D.C. Woman Just Made it Easier for You to Keep Your Independence, WAsh. Post (June 27, 2018), https://wapo.st/ 2nw4zaZ [https://perma.cc/H6W6-5ARB].

195. The case is an interesting one as in the end the senior was able to challenge her guardianship and have the court use supported decision making instead. Press Release, Quality Trust for Individuals with Disabilities: D.C. Senior Freed From Guardianship in Favor of Supported Decision-Making, (June 18, 2018). The woman's success in challenging her guardianship does not obviate the concern about the reluctance of providers of goods and services to enter into contracts with those whom they perceive to be people with disabilities. 
or conduct business with a person they perceive to lack capacity, for fear that the person is not able to understand what is happening, which could ultimately expose them to liability." ${ }^{196}$ These cases demonstrate that the mental incapacity doctrine as currently applied can pose a threat to the goal of integration.

\section{Rationality and Mental Incapacity}

The mental incapacity doctrine is at odds with the autonomy and independence goals of the DRM. One of the underlying policy justifications for the doctrine of mental incapacity is that people with mental disabilities need protecting, both from their own poor judgment and from those who would exploit and take advantage of them. ${ }^{197}$ The prevention of these harms is what justifies judicial intervention. One mechanism used by courts to protect people with disabilities is the assessment of the transaction's rationality. Using rationality as the test for the enforceability of the transaction is problematic for two reasons: first, behavioral economics challenges the assumption that decision-making is rational; second, the autonomy of people with mental disabilities may be undermined by requiring that their decisions be rational.

\section{Policing Through Rationality}

Poor judgment of the person with questionable capacity often leads to judicial inquiry about the rationality and economic viability of the contract. Courts may broadly inquire into the transaction's rationality to substantiate the claim of incapacity. The more holistically unfair the transaction, the more likely the person of questionable capacity did not have the legal capacity to enter the contract. A subset of these cases involves a specific inquiry into the economic value of the exchange or the consideration supporting the contract. If the exchange is grossly disproportionate, then this, among other factors, is evidence that the person economically harmed did not have the legal capacity to enter the contract. Courts will invalidate the transaction using the concept of gross inadequacy of consideration. Both the broad and the narrow approaches used by courts are discussed herein.

196. Beyond Guardianship, supra note 18, at 76. See generally Clinton Luth, The Color of Competency: The Differential Race Impact of Mental Health Assessment in Voidable Contracts, 20 J. Gender, RACE \& Just. 563 (2017) (discussing the interaction between mental disabilities and the legal system, particularly the impact of existing competency tests).

197. Friedman, supra note 13, at 20; Brucken et al., supra, note 17, at 1025; Green, Public Policies Underlying the Law of Mental Incompetency, $38 \mathrm{MicH.} \mathrm{L.}$ Rev. 1189, 1205-12 (1940). 
A number of courts have allowed rescission by a person with a mental disability on the basis the underlying transaction is economically irrational from the perspective of the person with the disability. Courts have long measured mental incompetence by considering the rationality of an action. ${ }^{198}$ Often the person seeking avoidance and rescission offers the irrationality of the transaction as evidence of the person's mental incompetency. ${ }^{199}$ The standard of review is whether "the particular transaction in its results is that which a reasonably competent man might have made." 200 This standard is based in part on Section 15(1)(b) of the Restatement (Second) of Contracts and the comments thereto.

Prior to adoption of the Second Restatement, the legal definition of mental incapacity was solely a cognitive one: the issue was whether the person was able to understand and appreciate the consequences of her actions and the nature of the transaction. The cognitive test for incapacity does not overtly require an inquiry into the wisdom or economic rationality of the transaction. Despite this, many jurisdictions did consider this factor. ${ }^{201}$ This led one prominent legal scholar to conclude that the economic fairness of the transaction was not just a factor in the court's analysis but was the dispositive factor in determining the legal capacity of a contracting party. $^{202}$ The more irrational or morally repugnant the transaction and the circumstances surrounding the contract's formation, the less evidence of incompetency is required by the court. ${ }^{203}$ Con-

198. See Meiklejohn, supra note 93, at 315-18; Green, Proof of Mental Incompetency, supra note 88 , at 281-304, 309.

199. Professor Peter Margulies labels approach as the outcome test of capacity. Peter Margulies, Access, Connection, and Voice: A Contextual Approach to Representing Senior Citizens of Questionable Capacity, 62 Fordham. L. Rev. 1073, 1982 (1994).

200. See Green, Proof of Mental Incompetency, supra note 88, at 309.

201. See Brucken et al., supra, note 17, at 1042 nn.117-18.

202. See Green, Proof of Mental Incompetency, supra note 88, at 275. Green argues that the fairness of the transaction is the only guiding principle that reconciles the wildly inconsistent results in incompetency cases; see also CORBIN ON Contracts $\$ 27.10$ (REV. ED. 2001); Williston, supra note 43, § 10.3; Maxine Boord Virtue, Restitution from the Mentally Infirm, 26 N.Y.U. L. REv. 132, 151 (1951); Lawrence Frolik \& Mary Radford, "Sufficient" Capacity: The Contrasting Capacity Requirements for Different Documents, 2 NAELA J. 303, 318 n.89 (2006) (citing Bach v. Hudson, 596 S.W.2d 673 (Tex. Civ. App. 1980)). Others challenge Green on this point, arguing that courts take a more global approach, with fairness being relevant, but not determinative. Meiklejohn, supra note 93, at 203.

203. See Oullette v. Ledoux, 30 A.2d 13, 16 (N.H. 1943); Schanck v. Hooper, 160 N.Y.S.627, 630 (N.Y. App. Div. 1916). But see Estate of McGovern v. Commonwealth, 517 A.2d 523 (Pa. 1986) at 526 (“... a presumption of mental incapacity does not arise merely because of an unreasonable or unnatural disposition of property."). 
versely, if the court determines the deal is fair, the bar for proving the mental incompetence of the contracting party is much higher. ${ }^{204}$

In 1981, the American Law Institute published the final version of the Restatement (Second) of Contracts. Included in the Second Restatement is Section 15(1)(b) which expands the definition of mental incapacity to include both a volitional test and cognitive test. ${ }^{205}$ Comments were added advising courts to consider the reasonableness of the transaction when evaluating whether a person satisfied the volitional test for mental incapacity. ${ }^{206}$ Many courts accepted this overt invitation and continue either directly or indirectly to assess the rationality of the actions of the party seeking rescission when determining whether the person was mentally incompetent. ${ }^{207}$ Slorby v. Johnson ${ }^{208}$ is instructive on this point. This case involved a conservator's attempt to rescind a contract for a deed transferring over 600 acres of farmland from one unrelated neighbor to another. The sale price of the land was $\$ 64,000$, although the land had a value of $\$ 240,000$ at the time of transfer; the contract provided for no down payment and had an interest rate three percent less than the market rate. ${ }^{209}$ The court expressly stated, "The low price and other favorable terms, while they may not alone be indicative of a person's mental capacity, could certainly be considered by the trial court as one of many factors in deciding whether Steffons was competent to execute the contract for deed." 210 The economic irrationality of the terms of the contract is treated as evidence of the grantor's incapacity.

The court in Hauer v. Union State Bank of Wautoma ${ }^{211}$ avoided a loan entered into by plaintiff based on incapacity even

204. See Margulies, supra note 199, at 1075 ("If the decisions appear 'right,' the individual possesses capacity. If the decisions are 'wrong,' the individual lacks capacity."). One commentator suggests that the courts' assessment or evaluation of the fairness of the transaction is the inevitable consequence of the use of the concept of the "ability to understand" the nature of the transaction contained in the definition of legal incompetency. He argues that the only way to determine the level of understanding of the person entering into the contract is to look at the objective manifestation of that understanding; there is a way that we can look into the mind of the person entering into the contract so all we are left with is the manifestation of that person's mind. See Weihofen, supra note 44, at 217. 1981).

205. Restatement (Second) of Contracts, § 15(1)(b) (Am. Law Inst.

206. Id. § $15 \mathrm{cmt} . \mathrm{b}, \mathrm{c}$.

207. See Sparrow v. Demonico, 960 N.E.2d 296, 303 (Mass. 2012); Farnum v. Silvano 540 N.E.2d 202, 204 (Mass. App. Ct. 1989).

208. Slorby v. Johnson, 530 N.W.2d 307, 310 (N.D. 1995).

209. Id. at 308 .

210. Id. at 313; see also Buchanan v. Prall, 167 N.W. 488, 489 (N.D. 1918).

211. Hauer v. Union State Bank of Wautoma, 532 N.W.2d 456, 466 (Wis. Ct. App. 1995). 
though the plaintiff could not restore the proceeds of the loan. The court noted the plaintiff suffered a brain injury in a motorcycle accident and that her monthly income after the accident was $\$ 900$, which consisted of social security disability and income from a mutual fund. ${ }^{212}$ Because she needed the funds to survive, it was economically unreasonable to use this money as collateral for a loan, of which she was not the direct beneficiary. ${ }^{213}$ The court allowed the avoidance and rescission of the loan based on mental incapacity, implicitly relying on the economic irrationality of the transaction to support the claim.

The relationship between the parties is an additional measure of the transaction's rationality. ${ }^{214}$ Courts consider factors such as the social context within which the transaction occurred, including the relationship between the impaired party, the party challenging the transaction, and the non-impaired party to the transaction. The court in Slorby may have been willing to rescind the deed because the grantees were not related to the grantor and did not care for him in any significant manner. ${ }^{215}$ The court's decision to avoid the loan in Hauer was influenced by the fact the borrower did not use the loan proceeds. Rather, the proceeds were used by someone unrelated to her-an individual the court portrayed as having taken advantage of her. ${ }^{216}$

The court is more likely to deem the transfer rational if there is a familial relationship or friendship between the two parties. ${ }^{217}$ In Butler v. Harrison, ${ }^{218}$ the beneficiaries of a wife's will challenged the quitclaim deed she signed; the deed transferred certain real property to herself and to her husband as tenants by the entirety. The beneficiaries alleged that the wife was mentally incompetent at the time of signing. In upholding the transaction, the court noted,

212. Id. at 459 .

213. Id.

214. See Virtue, supra note 202 , at 151 . Virtue stated,

that if it was a reasonable contract and the recipient was a worthy object of trust and faith, then that shows sufficient capacity to uphold the contract; but if support was not given ... then the grantor was incapacitated Id. because no-one in his right mind would have made such a contract.

215. Slorby v. Johnson, 530 N.W.2d 307, 308 (N.D. 1995) ("Peter's [grantee] contacts with Steffens [grantor] were limited to occasional visits at the Willard Johns Sr. home and one or two visits with Steffens while he resided in Minot with Olson.").

216. See Hauer, 532 N.W.2d at 466.

217. See Meikeljohn, supra note 93, at 361-67 (arguing that the social context within which the transactions occurred is highly relevant to court decisions as to avoidance and rescission).

218. Butler v. Harrison, 578 A.2d 1098, 1098-99 (D.C. 1990). 
"[N]othing in the record suggest[s] that Mrs. Harrison's action in executing the April 8, 1992[] deed was a bizarre conveyance." 219 That a wife was transferring property to her spouse, and not an unrelated person, may have influenced the court's decision to uphold the conveyance as reasonable. ${ }^{220}$

In Citizens State Bank v. Ruebel, ${ }^{221}$ the owner of property, who had signed a mortgage to secure a loan for her daughter and son-inlaw, sought to invalidate a mortgage based on mental incapacity. The appellate court remanded, requiring the trial court to hold a hearing on the issue of the landowner's competency. The appellate court noted that "it is difficult to look at this transaction and conclude that Citizens operated in good faith. Elsie was a vulnerable older Iowan whose only child was in the process of taking financial advantage of her. There is no evidence Elsie gained any financial advantage from the transaction." 222 Here, the court was influenced not only by the landowner's irrational economic decision but also by the fact that an ungrateful and greedy family member exploited her mother. This added to the overall substantive unfairness of the transaction.

The court in Farnum v. Silvano 223 voided the sale of real property when it found the seller incompetent. The court noted that the seller, who at the time of sale was ninety years old, had medical and other expenses she was required to pay. Thus, "it was not rational to part with a major asset for a cut-rate price." 224 The court additionally was influenced by the fact that the buyer-grantee was unrelated to the seller and had not cared for her for a lengthy period. Testimony revealed that this young man in his early twenties knew the seller because he performed yard work for her. This factor enhanced the apparent irrationality of the transfer.

Not all courts consider the transaction's rationality when assessing the mental incompetence of the person seeking to avoid the contract. In Estate of McGovern, ${ }^{225}$ the court expressly declined to follow Restatement (Second) Section 15(1)(b) and the attendant comments. At issue was the decedent's mental competency at the time he made the challenged retirement selection. The petitionerson argued, in part, that the irrationality of the option chosen evi-

219. Id. at 1101.

220. See Kirk v. Tackett, 279 N.W. 468, 470 (Neb. 1938).

221. Citizens State Bank v. Ruebel, No. 10-1028, 2011 WL 3116243, at *1 (Iowa Ct. App. July 27, 2011).

222. Id. at *4.

223. Farnum v. Silvano, 540 N.E.2d 202, 203 (Mass. App. Ct. 1989).

224. Id. at 205.

225. Estate of McGovern v. Commonwealth, 517 A.2d 523, 524 (Pa. 1986). 
denced the decedent's mental incompetence. The court refused to consider the economic rationality of the disposition when determining if the decedent was mentally competent. ${ }^{226}$

In Matter of Estate of Obermeier, ${ }^{227}$ the niece of the decedent challenged the sale of real property to the decedent's neighbor based on the aunt's mental incompetency. The majority upheld the transaction without discussing the economic rationality of the transaction or considering the decedent's relationship with the grantee, an unrelated neighbor, or with the petitioner, the decedent's niece. The dissent doubted the viability of the transaction by pointing to various pieces evidence. The sale price was less than half the appraised value of the property, the evidence concerning the mental incompetency of the grantor was compelling, and there were serious inconsistencies in grantee's testimony concerning his relationship with the decedent and the impetus for the transaction. ${ }^{228}$ The majority failed to address any of the dissenters' objections. Despite the refusal of some courts to assess a transaction's rationality, the majority heed the recommendations reflected in the Restatement by using this as a factor to determine whether the claimant was capable of entering into the contract.

A second way courts seek to protect people with mental disabilities from irrational transactions is by invoking the concept of gross inadequacy of consideration. Generally, contract law is private law, and the role of the state via the judiciary is limited to ensuring the formalities of the law have been satisfied. Traditionally, the judicial role in policing the substance of the agreement was very limited. A corollary to this limited scope of review is that courts will not invalidate a contract simply because what the parties exchange is not of equivalent economic value. ${ }^{229}$ According to traditional contract principles, courts will not weigh consideration. $^{230}$

Despite the strong policy against the judicial economic policing of agreements, courts regularly undermine this doctrine when a

226. Id. at 527; see also Bailey v. Bailey, 677 S.E.2d 56, 59 (2009) (citing Drewry v. Drewry, 383 S.E.2d 12, 15 (Va. Ct. App. 1989)). 1989).

227. In re Estate of Obermeier, 150 A.D.2d 863, 863-64 (N.Y. App. Div.

228. Id. at 865 .

229. Restatement (Second) of Contracts $\$ 79 \mathrm{cmt}$. c (Am. LaW Inst. 1981); see also 3 Williston on Contracts $§ 7: 21$ (4th ed. 1990).

230. See Alpha Capital Anstalt v. Real Goods Solar, Inc., 311 F. Supp. 3d 623, 631 (S.D.N.Y. 2018); CD Int'l Enter., Inc. v. Rockwell Capital Partners, Inc., 251 F. Supp. 3d 39, 45 (D.C. 2017); Peyton v. Peyton, 271 S.W.2d 493, 500 (Tex. Civ. App. 1954); Batsakis v. Demotsis, 226 S.W.2d 673, 675 (Tex. Civ. App. 1949). 
contracting party is of questionable capacity. ${ }^{231}$ Courts invoke gross inadequacy of consideration to justify avoiding a contract based on mental incapacity. ${ }^{232}$ Although not dispositive, evidence that a party entered into a contract that is extremely disadvantageous to her persuasively suggests incapacity. ${ }^{233}$

The use of evidence of gross inadequacy of consideration is not limited to establishing the incompetency of the contracting party. This evidence also may serve as a factor that, when combined with mental weakness, provides a basis for the invalidation of a transaction. The court in Gilliland v. Carpenter ${ }^{234}$ invalidated two deeds, arguing "this case presents a situation where the inadequacy of consideration is coupled with evidence of failing mental capacity of the grantor."235 This coupling provided the basis for invalidating the deeds. There was evidence the value of the land was $\$ 51,000$ on the date the parties signed the deeds, a value much greater than the $\$ 5,000$ purchase price. ${ }^{236}$ But the Gilliland court did not find the grantor legally incompetent. ${ }^{237}$ Indeed, the court conceded there was insufficient evidence to invalidate the deeds based solely on the grantor's mental incapacity. Despite this, and despite the general rule that courts should not weigh consideration, the court invalidated the deeds.

Gilliland is not an outlier. Other courts couple mental weakness short of incapacity with gross inadequacy of consideration to invalidate transactions. $^{238}$ These decisions do not always refer overtly to the irrationality of the transaction. However, by definition, when courts invoke the concept of gross inadequacy of consideration, the decisions infer that the exchange is economically irrational because the values are economically disparate. When in-

231. See In re Estate of Green, 755 So. 2d 1054, 1055 (Miss. 2000); Slaick v. Arnold, 728 S.E.2d 782, 785 (Ga. Ct. App. 2012). Note that evidence of weakness of intellect not rising to the level of legal mental incapacity may not be enough to justify avoidance or rescission even if there is inadequacy of consideration.

232. See Williamson v. Matthews, 379 So. 2d 1245, 1247 (Ala. 1980); RestateMent (SeCONd) of Contracts $\$ 79 \mathrm{cmt}$. e (Am. Law Inst. 1981); 26A C.J.S. Deeds $\$ 103$ (2019).

233. See Campbell v. Lux, 225 S.W. 653, 654 (Ark. 1920); Black v. Duffie, 508 S.W.3d 40, 43 (Ark. Ct. App. 2016).

234. See Gilliland v. Carpenter, 395 S.E.2d 779, 780 (W. Va. 1990).

235. Id. at 783; see also Bryant v. Bryant, 379 So. 2d 382, 383 (Fla. Dist. Ct. App. 1979).

236. Gilliland, 395 S.E.2d at 783.

237. Id.

238. See Allore v. Jewell, 94 U.S. 506, 510 (1876); Sheppard v. Clay Peacock Coal Co., 285 S.E.2d 902, 905 (W. Va. 1982); Dohrmann v. Swaney, 14 N.E.3d 605, 615 (Ill. App. Ct. 2014); Daughton v. Parson, 423 N.W.2d 894, 896 (Iowa Ct. App. 1988) (citing to Brewster v. Brewster, 188 N.W. 672, 674 (Iowa 1922)). 
validating these transactions, the court seeks to protect the assets of the person with a disability either for herself or for her beneficiaries and family members.

\section{Behavioral Law and Economics-Decision Making Is Irrational}

Whatever strategy courts employ to allow them to consider the rationality of the transaction, the question remains whether this should be a factor at all. ${ }^{239}$ The emphasis on rationality fails to consider the increasing evidence offered by behavioral economics that neurotypical people make irrational, poor decisions all the time. To invalidate only the irrational transactions of those with questionable capacity creates a double standard. ${ }^{240}$

The mental incapacity doctrine restricts the ability of a person with a mental disability to enter into economically irrational contracts. Courts implicitly or explicitly using this standard assume that contracts should be enforced against people with a mental disability only if the contracts are economically reasonable. ${ }^{241}$ This doctrine empowers courts to police these contracts in a way they may not for those without mental disabilities. Intervention on behalf of people with mental disabilities is questionable because it assumes that people without mental disabilities make rational decisions. However, research by behavioral economists challenges this fundamental assumption of rationality. ${ }^{242}$

239. For a critique of the application of the reasonable man standard in law of torts to cases involving the disabled see tenBroek, supra note 16, at 912-18. For a discussion supporting rationality see Stephen J. Morse, Crazy Reasons, 10 J. CoNTEMP. LegAL Issues 189 (1999).

240. See Deborah W. Denno, Sexuality, Rape, and Mental Retardation, 1997 U. ILl. L. REv. 315, 394 (1997) (arguing that current capacity law unjustifiably holds people who are mentally retarded to a higher capacity standard than those who are not similarly impaired).

241. The court in Estate of McGovern expressly rejected the concept that irrationality of a decision proves incompetence and thus justifies intervention by the court:

Thus, the claim that is made here in the name of incompetence is in reality a challenge to the wisdom, the desirability, the thoughtfulness and the rationality of the disposition. But such a challenge may not succeed, for neither courts nor disappointed heirs may alter the disposition of the property of a deceased person merely on the grounds that that person acted in a way that the challenger believes to be irrational.

Estate of McGovern v. Commonwealth, 517 A.2d 523, 528 (Pa. 1986).

242. See Joshua D. Wright, Behavioral Law and Economics, Paternalism, and Consumer Contracts: An Empirical Perspective, 2 N.Y.U.J.L. \& LiBERTy 470, 471 (2007); see also Susan Block-Lieb \& Edward Janger, The Myth of the Rational Borrower: Rationality, Behavioralism, and the Misguided "Reform" of Bankruptcy Law, 84 Tex. L. Rev. 1481, 1531 (2006). 
Behavioral economic theory challenges using the rationality of the transaction as a basis for assessing incapacity and the enforceability of the contract. ${ }^{243}$ Courts that evaluate the capacity of a person based on the rationality of the transaction are harkening back to a fundamental concept that underlies Anglo-American law: that of the reasonable man. ${ }^{244}$ This concept permeates all areas of the law, including criminal law, torts, and, of course, contract law. Contract law generally, and the mental incapacity doctrine specifically, have embraced this norm. ${ }^{245}$ This is reflected in the decisions discussed above as well as the Restatement (Second) of Contracts Section 15. The law assumes that parties to contracts are rational actors, that they have perfect information, and that they can accurately analyze that information before making a decision. ${ }^{246}$ Legal accountability for one's actions often rests on the question of whether those actions were the product of rational thought processes. Under many legal doctrines, the more intentional the actions of the person, the more legal liability is imposed. Thus, the

243. Behavioral economist Alain Samson summarizes the basic tenets of behavioral economics:

- People are not always self-interested, benefits maximizing, and costs minimizing individuals with stable preferences

- Most choices made by people are not the result of careful deliberation

- Choices are influenced by insufficient knowledge, feedback, and processing capability

- People are influenced by readily available information

- People live in the moment, resist change, and are subject to distorted memory

- People are social animals with social preferences and are susceptible to social norms

See generally Alain Samson, An Introduction to Behavioral Economics, in THE BEhavioral Economics Guide, 1 (1st ed. 2014). Samson's Introduction is premised on the groundbreaking work of psychologists Daniel Kahneman and Amos Tversky, and economist Richard Thaler.

244. See Melvin A. Eisenberg, Behavioral Economics and Contract Law, in The Oxford Handbook of Behavioral Economics and the Law 438, 443 (Eyal Zamir \& Doron Teichman eds., 1st ed. 2014). I purposely use the reasonable "man," not reasonable "person," as when the concept originated, women were not universally considered to have legal capacity.

245. See Friedman, supra note 13, 20-22.

246. See Eisenberg, supra note 244, at 439.

Rationality, for this purpose, requires that an actor possesses and accurately processes all readily available information concerning the outcomes of alternative choices, ranks the possible outcomes in order of their expected utility, understands probability, and properly discounts future states of the world when comparing them with present states of the world.

Id.; see also Block-Lieb \& Janger, supra note 242, at 1526 (explaining rational choice theory presumes that individuals possess the intellectual capacity to identify their preferences, to maximize their utility when possible, and to act rationally under conditions of uncertainty when necessary). 
law inquires whether the person subject to legal liability acted negligently, recklessly, or intentionally. ${ }^{247}$ In measuring each of these, courts traditionally ask what a reasonable man would have done under similar circumstances. The following excerpt conveys, somewhat ironically, the essence of the reasonable man:

$\mathrm{He}$ is one who invariably looks where he is going, and is careful to examine the immediate foreground before he executes a leap or a bound; . . . who believes no gossip, nor repeats it, without firm basis for believing it to be true; ... who in the way of business looks only for that narrow margin of profit which twelve men such as himself would reckon to be 'fair'. .; who uses nothing except in moderation, and . . . is meditating only on the golden mean. Devoid, in short, of any human weakness, with not one single saving vice, sans prejudice, procrastination, ill-nature, avarice, and absence of mind ... this excellent but odious character stands like a monument in our Courts of Justice, vainly appealing to his fellow-citizens to order their lives after his own example. ${ }^{248}$

While this excerpt is sardonic, the truth remains that the reasonable man (now the reasonable person) continues to haunt legal doctrine.

The theory of law and economics embraces and reifies the reasonable person. A basic tenet of law and economics is the rational choice theory, developed by economists in the 1950s. ${ }^{249}$ The rational choice theory presumes individuals possess the intellectual capacity to identify their preferences, to maximize their utility when possible, and to act rationally under conditions of uncertainty whenever necessary. ${ }^{250}$ In economics, the standard approach assumes "full rationality." ${ }^{251}$ Full rationality includes the following basic components: 1) people have well-defined preferences (or goals) and make decisions to maximize those preferences; 2) those preferences accurately reflect (to the best of the person's knowledge) the true costs and benefits of the available options; and 3) in situations that involve uncertainty, people have well-formed beliefs about how uncertainty will resolve itself, and when new information

247. See Nat'l Council on Disability, supra note 18 , at 74 .

248. A.P. Herbert, Misleading Cases in the Common Law 14-16 (4th ed. 1930).

249. See Thomas S. Ulen, The Importance of Behavioral Law, in The Oxford Handbook of Behavioral Economics and the Law 93 (Eyal Zamir \& Doron Teichman eds., 2014); see also Eisenberg, supra note 244, at 442.

250. Block-Lieb \& Janger, supra note 242, at 1526.

251. Colin Camerer et al., Regulation for Conservatives: Behavioral Economics and The Case for "Asymmetric Paternalism," 151 U. PA. L. Rev. 1211, 1214 (2003). 
becomes available, they update their beliefs. ${ }^{252}$ Economic theory posits that, normatively and descriptively, the law should be governed by rationality and should assume the reasonable person standard applies.

Behavioral economists and psychologists argue that rational choice theory does not sufficiently explain human behavior. ${ }^{253}$ Modern legal scholars frequently and increasingly base their analyses not on the neoclassical economics assumption of rationality but on the assumption individuals are subject to a number of systematic behavioral biases, such as bounded rationality, errors in judgment, and non-standard preferences. ${ }^{254}$ The concept of bounded rationality posits that actors rarely make fully informed decisions. ${ }^{255}$ Instead, human rationality is normally bounded by limited information and limited information-processing ability. ${ }^{256}$ Pursuant to this theory, even individuals whose mental capacity is not called into question may be neurologically unable to process information needed to weigh the costs and benefits of a particular choice, thus leading to an irrational decision. Actors often lack the ability to process information perfectly ${ }^{257}$ because of neuropsychological limits of the brain and definitional limits inherent in language. ${ }^{258} \mathrm{Cog}$ nitive experiments show that individuals adopt timesaving strategies to simplify complex decision-making; however, sometimes this results in biased decision making. ${ }^{259}$

Behavioral psychology also contends that defects in disposition and in capability may lead to irrational decision making. Actors may have a defect in their disposition because they are unrealisti-

252. Id. at 1214-15; see also Botond Koszegi, Behavioral Contract Theory, J. Econ. Literature, Dec. 2014, at 1075, 1085 (describing the Quasi-Bayesian approach to be where an actor updates her beliefs consistent with Bayes's law but commits a particular error that is inconsistent with rational inference).

253. See Ulen, supra note 249, at 93, 96 (explaining that behavioral experiments suggest human beings do not behave as rational choice theory predicts and that they do not typically make decisions that enhance their welfare as much as they might).

254. Wright, supra note 242, at 471 ("Although some scholars have challenged this empirical literature, they have not generally denied the existence of cognitive biases, or the possibility that behavioral models might have greater predictive power" of an actor's behavior); see Cass R. Sunstein, Behavioral Law and Economics: A Progress Report, 1 Am. L. \& Econ. Rev. 115, 121 (1999) ("The notion of 'quasi-rationality' should be taken to suggest departures from standard economic assumptions, but departures that are systematic and predictable, and thus a legitimate basis for predicting human behavior.").

255. See Eisenberg, supra note 244, at 443.

256. Id.

257. Id.

258. Id.

259. See Block-Lieb \& Janger, supra note 242, at 1531. 
cally optimistic. ${ }^{260}$ An actor may have a defect in capability if she is unable to make rational comparisons between the present and future-also referred to as the "faulty telescope faculty."261 Myopia can explain an actor's impulsive behavior or inability to act rationally. ${ }^{262}$ Capability defect also may manifest in the form of systematic underestimation of risk when actors are unable to or choose to ignore the possibility of future risks. ${ }^{263}$

Behavioral economic theory can be applied to any number of cases involving mental incapacity. The defect in disposition that results in unrealistic optimism can explain the choice made by the decedent in Ortelere. ${ }^{264}$ The decedent, Mrs. Ortelere, changed her retirement benefits so that upon her death, her spouse would not receive any remaining benefits. Mrs. Ortelere's spouse successfully challenged the election based on Mrs. Ortelere's mental incapacity, arguing her selection was irrational. However, this choice can be explained as her being unrealistically optimistic about her longevity. She made this decision assuming she would live long enough to enjoy the benefits of her retirement. While the court took this as evidence of lack of mental capacity, behavioral economic theory provides an alternative explanation. The decision made by Mrs. Ortelere is a decision that could have been made by anyone, regardless of mental capacity. The irrationality of this decision might not have been a sufficient basis for avoiding her election.

The inability to make rational comparisons between the present and the future can also explain decisions made by those whose capacity is questionable. People who have transferred assets despite the evident need for those assets for their future care may simply be exhibiting a defect in capability. For instance, the trans-

260. See id. at 1540-41 (showing consumers have difficulty assessing the likelihood that they will lose their job, get sick, get a divorce, have a child; this is also known as overconfidence bias); Sunstein, supra note 254 at 136-37.

261. Eisenberg, supra note 244, at 447 (explaining that actors tend to "give too little weight to future benefits and costs as compared to present benefits and costs"); Oren Bar-Gill, Consumer Transactions, in The Oxford Handbook of BEHAVIORAL ECONOMICS AND THE LAW 465, 474 (describing that myopic consumers care too much about the present and not enough about the future; consumers tend to underestimate the probability of triggering the contingent, future costs); Block-Lieb \& Janger, supra note 242 at 1543-44 (explaining that the impulse for immediate gratification is often irresistible in spite of any long-term consequence, i.e., individuals are more likely to finance purchases than wait until they can pay in full).

262. See Sunstein, supra note 254 , at 122.

263. See Eisenberg, supra note 244, at 447 (citing cognitive psychologist Kenneth Arrow's observation that there is a tendency to underestimate uncertainties).

264. Ortelere v. Teachers' Ret. Bd., 250 N.E.2d 460, 466 (N.Y. 1969). 
fer by the grantor in Farnum, ${ }^{265}$ in which the ninety-year-old grantor deeded her house to her twenty-five-year-old gardener, can be explained by behavioral economic theory. The court noted the transaction was irrational, as the grantor needed the asset to pay for her living and medical expenses. However, this decision can be explained by the grantor's inability to anticipate accurately the future and her need to have the asset available for her support. Her inability to assess risk accurately is not evidence of mental incapacity. Rather, it is a reflection of her humanity.

If behavioral economists are right and we all make less than optimal economic decisions, why distinguish those with mental disabilities? Unimpaired people who make economically poor contractual decisions are bound to those decisions. The same is not true for those with mental disabilities. If both the impaired and the unimpaired make irrational decisions not governed by benefit maximization, then the underlying justification for the mental incapacity doctrine must be called into question. ${ }^{266}$ The reasonable man turns out to be nothing more than a myth; some might say good riddance! As a result, the law binds unimpaired people to irrational contracts but excuses the mentally impaired from such contracts. Disability advocates argue that people with mental disabilities should be allowed to make poor, even economically irrational decisions just as the unimpaired do. ${ }^{267}$ Protection from making mistakes reduces the self-determination and thus the humanity of those with mental disabilities. Based on this concept, judicial intervention allowing the people with a mental disability to avoid their contractual liability is patronizing and, to a degree, dehumanizing. ${ }^{268}$

\section{Rationality, Autonomy, and the Dignity of Risk}

When courts use the mental incapacity doctrine to question the rationality of the transaction, they do so in the name of protecting

265. Farnum v. Silvano, 540 N.E.2d 202, 203 (Mass. App. Ct. 1989).

266. A counter argument that deserves exploring in a follow-up essay is the question of whether the ability, or inability, to correct for bias justifies the continued need for the incapacity doctrine. Neurotypical people may be able to correct for cognitive error once they become aware of the error or their own biases. To the extent that this is not true for people with certain kinds of mental disability, the protection of the doctrine may be justified.

267. See Nat'l Council on Disability, supra note 18 , at 82.

268. A weakness of the dignity of risk argument in this context is that often we want people to make mistakes so that they can learn from them and then subsequently make better choices. Query whether this makes sense in the context of a person with a permanent mental disability whose disability does not allow for this increased decision-making ability. 
the person with a mental disability. ${ }^{269}$ When a person with a mental disability makes a decision that reduces their financial resources, courts consistently determine such a decision is irrational and subject to reversal. "Protection" thus translates to the preservation of these assets and resources. ${ }^{270}$ The person with the disability may need these resources for their care, or these resources may be assets in which the person's relatives, beneficiaries, or heirs have a potential financial interest. ${ }^{271}$ As one author notes, "[a]n appreciable number of cases brought by the nominal representative of the incompetent involve fact situations in which the representative's position is not identified with the welfare or immediate legal interests of the incompetent." 272 When a court polices agreements entered into by someone with mental disabilities, the person's assets may be redistributed in ways that are inconsistent with that person's wishes. ${ }^{273}$ This violates the autonomy of the person with a mental disability. ${ }^{274}$ The DRM has challenged legal actions that impinge

269. A study conducted of people confined to a mental institution challenges the notion that people with mental disabilities do not or cannot make rational decisions. The study compared the responses of the mental patients with those of the employees of the facility to questions about contemporary social and political issues. The study authors concluded, "[T]he results do not suggest that the mental patients in our sample are more illogical, inconsistent, or unprepared to fulfill their obligations as citizens than a similar group of individuals who are not identified as emotionally unstable." Marguerite R. Hertz et al., Mental Patients and Civil Rights: A Study of Opinions of Mental Patients on Social and Political Issues, $1 \mathrm{~J}$. Health \& Hum. Behav. 251, 258 (1960).

270. See, e.g., Weaver v. Carothers, 153 So. 201, 202 (1934).

271. One author conducted a study of over 800 mental incapacity cases. Of the cases in which the contracts were enforced (which was about one-half of the total 800 cases), fewer than one-fourth involved the parties to the contract. Guardians, heirs, executors, or administrators brought the others. Of the contracts that were avoided, about one-eighth of the cases were between the immediate parties. Guardians, heirs, executors, administrators, or nexts-of friend brought the remainder. Virtue, supra note 202, at 149-50.

272. Id. at 150.

273. Id. at 142 ("Avoiding the contract and protecting the lunatic, therefore, are not necessarily equivalent.").

274. The concept of autonomy and its relevance to people with disabilities, particularly intellectual or mental disabilities, is a contested one within the disability studies and Disability Rights Movement. This essay does not engage in this debate but provides this short synopsis: at issue is whether the liberal political concept of autonomy results in the exclusion of people with disabilities from the political and economic life of a society. This has led scholars and activists to challenge the definition, to give the concept an alternate reading, and to reject the concept entirely as a goal of the Disability Rights Movement. A sampling of this debate can be found in the following sources: see generally CAREY, supra note 163; Martha Albertson Fineman, Cracking the Foundational Myths: Independence, Autonomy, and Self-Sufficiency, 8 Am. U. J. Gender Soc. Pol'y \& L. 13 (2000); Eva Feder Kittay, Love's Labor: Essays on Women, Equality and Dependency (1999); Martha Minow, Making All the Difference: Inclusion, Ex- 
upon the personal autonomy of people with mental disabilities, as well as the actions and restrictions placed on people with mental disabilities for the sake of protecting them. ${ }^{275}$ The ADA, in its section identifying the statute's purpose, expressly provides that "individuals with disabilities continually encounter various forms of discrimination, including . . overprotective rules and policies." 276

Invalidating a transaction because it is economically irrational shields the person with a mental disability from the negative financial consequences of her actions. Increasingly, however, disability activists are resisting this insulation from liability. The "dignity of risk" principle captures this resistance to shield people with disabilities from the consequences of poor decisions. This concept was articulated by Robert Perske ${ }^{277}$ and embraced by others disability advocates. ${ }^{278}$ Pursuant to the dignity of risk, those who are cognitively or neurologically impaired are entitled to experience life as others do, including assuming a certain amount of risk. Perske and his adherents argue the goal should not be to protect people with mental disabilities. Rather, people with mental disabilities should be equipped with the tools to manage risk and the failures that may follow. ${ }^{279}$ Human dignity demands preparation, not protection. Human development requires not only the right to make choices but the ability to assume personal responsibility for those choices regardless of failure or even physical harm. ${ }^{280}$

Overt appeal of the autonomous decision making of people with mental disabilities is rare in cases outside of the guardianship context. In one case, a court articulated concern about the threat

Clusion, and American Law (1990); Martha C. Nussbaum, Frontiers of Justice: Disability, Nationality, Species Membership (2006).

275. See generally Bagenstos, supra note 142; Berkowitz, Disabled Policy: America's Programs for the Handicapped (1987); Charlton, supra note 38; AMERICANS WITH Disabilities: EXPloring IMPLiCATIONS OF THE LAW FOR Individuals and Institutions (Leslie Pickering Francis \& Anita Silvers, eds., 2000); Robert M. Levy \& Leonard S. Rubenstein, The Rights of PeOple with Mental Disabilities (1996); Shapiro, supra note 155; Stephen M. Shore, Beyond the Wall: Personal Experiences with Autism and AsPERGER Syndrome (2d ed. 2003).

276. Americans with Disabilities Act of 1990, 42 U.S.C. $\S 12101(a)(5)$ (2017).

277. Robert Perske, The Dignity of Risk and the Mentally Retarded, 10 Mental Retardation 24, 26 (1972).

278. Bagenstos, supra note 142, at 90-94; Gerben DeJong, Defining and Implementing the Independent Living Concept, in IndePendent Living FOR PhysiCally Disabled People, supra note 179, at 4, 20; Nat'l Council on DisabiLITY, supra note 18, at 47; Irving Kenneth Zola, Toward Independent Living: Goals and Dilemmas, in Independent Living fOr Physically Disabled PeOple, supra note 179, at 344, 351-53.

279. See Perske, supra note 277, at 26.

280. BAgEnstos, supra note 142, at 77-94; Zola, supra note 278 , at 351-53. 
the incapacity doctrine posed to autonomy. The court in Bell v. Smith $^{281}$ expressed this concern by upholding a contract entered into by a father and challenged by his adult son: "[i]t would be very serious if the law should say that whenever the faculties of a man began to fail because of his age it should be reason sufficient for taking from him the right to control his property." 282 The court was concerned about disempowering the father due to the natural decrease in mental acuity that sometimes accompanies aging. Pursuant to the dignity of risk, the father was entitled to dispose of his property as he saw fit, even if his decision was economically irrational from the perspective of his child and even if it put the father's assets at risk.

Returning to Renchard, the plaintiff may have made an economically foolish decision to liquidate his trust fund and spend $\$ 1.4$ million on a yacht. In that case, the court refused to grant the defendant-seller's motion to dismiss and found that there were material facts at issue concerning the plaintiff's capacity to enter into contracts. It is possible the court attempted to use the mental incapacity doctrine to protect the plaintiff from an economically poor decision. However, the dignity of risk principle would challenge this action, upholding the plaintiff's right to make this poor decision even if it left the plaintiff economically worse off.

By insisting on protecting people with mental disabilities through the mental incapacity doctrine, courts undermine the autonomy of people with mental disabilities. This may be easier to justify when the person has been adjudicated incompetent, but absent that determination, the interference may be unwarranted. ${ }^{283}$ By intervening via the mental incapacity doctrine, courts expand the circle of protection while simultaneously restricting the autonomy and dignity of the person with the disability.

\section{E. Consequences}

The plaintiff in the Renchard hypothetical I posed at the beginning of this essay attempted to avoid his contractual liability by arguing he did not have the requisite mental capacity to enter into the disputed contracts. Under the proposed limitation to the doctrine, the plaintiff would be unable to raise the mental incapacity doc-

281. Bell v. Smith, 32 N.Y.S. 54 (N.Y. Gen. Term 1894), cited with approval in In re Gebauer's Estate, 361 N.Y.S.2d 539, 552 (N.Y. Sur. Ct. 1974).

282. Bell, 32 N.Y.S. at 56.

283. For a discussion of this tension between autonomy and protection in the context of elderly people with questionable capacity, see Rein, supra note 18, at $1164-68$. 
trine, as he had not been adjudicated mentally incompetent. Indeed, under my proposed revision, the doctrine could not be raised in most of the cases considered in this essay. The revision creates a bright line between those who have been adjudicated incompetent and are thus subject to plenary guardianship and those who have not and are not. This section addresses some qualms about the proposal without necessarily resolving them. These are additional questions to consider as we contemplate the evolving relationship between contracts and people with mental disabilities.

First, will my proposal, in fact, alleviate the anxiety a seller/ lender might experience when dealing with a customer with a mental disability? A bright line test could help if, during contract negotiations, the Title III seller/lender could tactfully elicit from the potential customer whether they are currently subject to a guardianship, either plenary or limited. If limited, the follow-up question could be whether the customer retained the authority to enter into this particular type of transaction. Actual knowledge that the potential customer was not subject to a guardianship would remove incapacity as a disincentive to engage in the transaction, which would be a desirable result.

Additionally, and of critical importance for the purposes of this essay, it is unlikely that refusing to enter into a transaction with a person subject to plenary guardianship would violate Title III of the ADA. The ADA's definition of discrimination includes the imposition of eligibility criteria that screen out or tend to screen out an individual with a disability or a class of individuals with disabilities. ${ }^{284}$ On its face, screening out those people with disabilities who are subject to a guardianship would constitute discrimination under this section of the ADA. However, the section provides an exception that such criteria are permissible when they are "necessary for the provision of the goods[ or] services . . . being offered."285 A business subject to Title III could make a plausible argument that refusing to contract with a person adjudicated incompetent fits within the exception provided by the statute. Thus, my proposal could act as a safe harbor for entities subject to Title III of the ADA, reducing uncertainty and conflict and thus promoting contractual relationships with people with mental disabilities not subject to plenary guardianships.

Entities subject to Title III of the ADA would exercise more care when contracting with people with mental disabilities who are

284. See Americans with Disabilities Act of 1990, 42 U.S.C. $\S 12182(\mathrm{~b})(2)(\mathrm{A})(\mathrm{i})(2017)$.

285. Id. 
subject to a limited guardianship. Limited guardianships grant people with mental disabilities decision-making capacity over some aspects of their lives. People with mental disabilities subject to limited guardianships are able to enter into certain contracts, and a covered entity would violate Title III if, based on the disability, it failed to enter into a contract with them. An appealing aspect of my proposal is that it is consistent with the underlying goals of limited guardianship laws. The person with the mental disability would be accountable for all contracts entered into in the categories left untouched by the guardianship. Thus, if the court mandates that a person with a mental disability have control over housing, any contract the person enters into regarding housing would not be subject to attack based on the incapacity doctrine. This seems consistent with the goal of a limited guardianship which is to empower the person with the mental disability. This also is consistent with dignity of risk which empowers the person with a mental disability to make decisions even if those decisions have negative consequences. ${ }^{286}$

A further concern is whether the revised rule could incentivize representatives to seek plenary guardianship instead of limited guardianship for a person with a mental disability. This is a serious risk, as disability rights activists, scholars, and legislators have justifiably attacked plenary guardianships for many years. ${ }^{287}$ However, the proposed restriction would require the person seeking to avoid the contract be adjudicated incompetent before the person entered into the contract, not thereafter. Subjecting a person to a guardianship after the contract would not allow the person retroactively to use the mental incapacity doctrine to challenge the contract. This proposed change might disincentivize the establishment of a guardianship, as it becomes irrelevant to the enforceability of the contract.

286. The bright line test I propose does not address the serious challenges presented by guardianship. Economic rationality and the use of stereotype are used in assessing competence in guardianship proceedings; this essay does not address the appropriateness of using these factors in guardianship proceedings. However, the arguments I have made herein could certainly be applied to guardianship proceedings. While acknowledging that this is the case, I have chosen not to explore that issue here.

287. For articles exploring critiques of plenary guardianship, see Lawrence A. Frolik, Plenary Guardianship: An Analysis, A Critique and A Proposal for Reform, 23 Ariz. L. Rev. 599 (1981); Nancy J. Knauer, Defining Capacity: Balancing the Competing Interests of Autonomy and Need, 12 Temp. Pol. \& C.R. L. Rev. 321 (2003); Roger Sherman, Guardianship: Time for a Reassessment, 49 FordHAm L. Rev. 350 (1981); Jan Ellen Rein, Preserving Dignity and Self-Determination of the Elderly in the Face of Competing Interests and Grim Alternatives: A Proposal for Statutory Refocus and Reform, 60 Geo. WASH. L. Rev. 1818 (1992). 
Currently, the post-contract adjudication of incompetency can be offered as evidence that the person was mentally incompetent when they entered into the contract. My proposed change would render this evidence irrelevant.

I also have concerns about the socio-economic impact of the proposal. To take advantage of the incapacity doctrine, someone in the orbit of the person with a mental disability would be required to establish either a guardianship or a conservatorship. The process of establishing a guardianship is expensive, and navigating the process takes a certain amount of acumen and access to non-financial resources. ${ }^{288}$ Courts assess fees to file the petition. If an attorney prepares and files the petition, the person seeking to establish the guardianship will incur attorney fees. The court will establish a guardianship when it determines that the person with a mental disability is mentally incompetent. Establishing incompetency requires examination and assessment by health care professionals, such as physicians, who charge for their services. Generally, counsel, who charges for assistance, must represent the person with the mental disability. ${ }^{289}$ Further, if the court establishes a guardianship, there are ongoing expenses related to the management of the affairs of the ward.

Given the costs associated with this process, there is a risk that my proposal would allow only those who could afford to establish a guardianship to use the incapacity doctrine. Consequently, those unable to afford the guardianship process but who would benefit from the protection offered by the mental incapacity doctrine would be priced out of its protection. It is difficult to measure the impact the elimination of the mental incapacity doctrine would have on those unable to afford the guardianship process. Accessing the legal system is financially burdensome already. Even without my proposed restriction, those challenging contracts based on mental incapacity typically do so if there are assets at issue and if they can hire counsel.

Additionally, many of the costs incurred when establishing a guardianship would be incurred in an incapacity suit. A complainant seeking to invalidate a contract based on incapacity would incur

288. For a summary of the costs that can be incurred in establishing and maintaining a guardianship or conservatorship, see Julie Garber, How Much Does Guardianship or Conservatorship Cost?, ThE BALANCE, https://bit.ly/2yKulsd [https://perma.cc/3PZY-P2JH] (updated Sept. 04, 2019).

289. Anecdotally, a colleague who has recently been involved in seeking to establish a guardianship for a relative with dementia estimates that the initial cost will be approximately $\$ 15,000$. This does not factor in the ongoing management costs and fees that may be incurred. 
filing fees, expert witness fees, and attorney fees. There may be a class of persons who could afford to challenge a contract but who could not afford to pursue a guardianship. People may not have the resources to seek a guardianship or litigate the avoidance of a contract based on mental incapacity. If the latter is true, then the proposed rule does not negatively affect them.

My proposed restriction also has the potential to limit judicial discretion. Courts currently apply the mental incapacity doctrine inconsistently and manipulate the requirements of the doctrine to arrive at decisions they deem are fair. ${ }^{290}$ Even the requirements of notice and restitution are not applied consistently; courts tend to treat them as factors rather than as requirements. ${ }^{291}$ Under my proposed rule, claimants with questionable capacity could not invoke the doctrine of mental incapacity unless they were adjudicated mentally incompetent. This could bind a person to a contract that, under the circumstances, is economically harmful to the interests of the person with a mental disability or someone with an interest in the assets of that person. Some would support this restriction on judicial discretion; anti-sanists, for instance, might applaud limiting the judicial ability to impose rationality as a standard for measuring the validity of a contract entered into by a person with a mental disability. ${ }^{292}$ Others would rue the limitation based on the compelling argument that the courts should do justice, not simply apply rules blindly and strictly. The next section suggests a response to the concern that limiting the mental incapacity doctrine would increase vulnerability.

290. Green, Proof of Mental Incompetency, supra note 200, at 306-11; Meiklejohn, supra note 93, at 353; Virtue, supra note 202, at 140. For articles discussing the concern about judicial discretion and mental incapacity more broadly, see Knauer, supra note 287, at 341-47; Susan Stefan, Silencing the Different Voice: Competence, Feminist Theory and Law, 47 U. Miami L. Rev. 763 (1993).

291. Virtue, supra note 202, at 140.

292. Michael Perlin, a leading proponent of anti-sanism, has written extensively about the judicial bias towards sanism. See Michael Perlin, "Half-Wracked Prejudice Leaped Forth": Sanism, Pretextuality, and Why and How Mental Disability Law Developed as it Did, 10 J. Contemp. Legal Issues 3, 14-15 (1999) ("Judges are not immune from sanism. . . . Their language demonstrates bias against mentally disabled individuals and contempt for mental health professions."). See generally, Michael Perlin, Pretexts and Mental Disability Law: The Case of Competency, 47 U. Miami L. Rev. 625 (1993); Michael Perlin, On "Sanism," 46 S.M.U. L. Rev. 373 (1992); Michael Perlin, "Morality and Pretextuality, Psychiatry and Law: Of "Ordinary Common Sense," Heuristic Reasoning, and Cognitive Dissonance, 19 Bull. Am. Acad. Psychiatry \& L. 131 (1991). 


\section{Alternatives to Mental Incapacity}

This essay does not propose the complete elimination of the doctrine of mental incapacity. There may be some instances in which public policy requires relieving a person with a mental disability from her obligation to perform a contract. This section briefly considers whether other contract doctrines used to police the behavior of the parties would be sufficient substitutes for mental incapacity. It specifically considers whether the doctrines of undue influence and unconscionability would be adequate substitutes for the mental incapacity doctrine in circumstances where there has been some form of injustice or abuse on the part of the competent party. ${ }^{293}$ Complainants often plead these doctrines in conjunction with mental incapacity to avoid a contract. ${ }^{294}$ For those not adjudicated incompetent, these doctrines are more appealing than the mental incapacity doctrine because they avoid the stereotyping and stigma associated with mental disability.

\section{A. Undue Influence}

The doctrine of undue influence may be invoked by a complainant when one party has taken undue advantage of another who, for any number of reasons, is in a weakened state. Successful invocation of the doctrine allows the weakened party to avoid the contract, although the law requires this party to pay restitution. ${ }^{295}$ Generally, a claimant must prove two elements to establish undue influence: first, the party seeking to avoid and rescind the contract must show they were unduly susceptible when the contract was formed; and second, the avoiding, weakened party must show that

293. This review is intentionally cursory; the goal is to introduce the idea that other contract doctrines could be used as substitutes for the mental incapacity doctrine. To read more extensively on this topic, see generally Milton Green, Fraud, Undue Influence and Mental Incompetency, 43 Colum. L. Rev. 176 (1943); Michael L. Perlin, Pamela R. Champine, Henry A. Dlugacz, Mary A. Connell, Competence in the Law: From Legal Theory to Clinical AppliCATION 213-19 (2008).

294. See State Farm Life Ins. Co. v. Tidmore, No.: 7:14-cv-00657-SGC, 2016 WL 5390630, at *2 (N.D. Ala. Sept. 27, 2016); Jackson v. Schrader 676 N.W.2d 599, 602 (Iowa 2003); Farnum v. Silvano, 540 N.E.2d 202, 205 (Mass. App. Ct. 1989); Schanck v. Hooper, 160 N.Y.S. 627, 630 (N.Y. App. Div.1916); In re Estate of Gebauer, 361 N.Y.S.2d 539, 543-44 (N.Y. Sur. Ct. 1974); Estate of Wenzel-Mosset by Gaukler v. Nickels, 575 N.W.2d 425, 428 (N.D. 1998); Dubree v. Blackwell, 67 S.W.3d 286, 288 (Tex. App. 2001); Green, supra note 293, at 190; Meiklejohn, supra note 93 , at 267.

295. Restatement (Third) of Restitution and UnJust Enrichment $§ 15$ (Ам. Law Inst. 2011). 
the other party exerted undue pressure in soliciting her assent to the terms of the contract. ${ }^{296}$

The oft-cited case Odorizzi v. Bloomfield School District ${ }^{297}$ is instructive on both elements of undue influence. As to the first element, the Odorizzi court indicated undue influence, or susceptibility, can range from total incapacity to weakness of mind caused by emotional anguish, infirmity or old age, or any combination of these factors. It need not be permanent; one need only to have been in a weakened mental state when the parties entered into the contract. ${ }^{298}$ In challenging the validity of his resignation letter, the plaintiff in Odorizzi established that he was mentally and emotionally vulnerable and thus in a weakened state because he signed the letter immediately upon his release from police custody. He was arrested, charged with a crime, held at the police station and questioned for 40 hours, and had just returned home when school board officials arrived to demand his resignation. ${ }^{299}$ The court found that he did not have the capacity necessary to freely enter into a contract. ${ }^{300}$

Applying the first factor of undue susceptibility to people with mental disabilities will yield very individualized results, as the degree to which a person will be rendered "weak of mind and will" depends on the nature of their disability. ${ }^{301}$ If the claimant pleads both mental incapacity and undue influence, they will submit a common set of facts. ${ }^{302}$ Under this circumstance, the undue influence doctrine may be subject to the same risk of stereotype reinforcement as the mental incapacity doctrine. Because the claimant is trying to persuade the fact finder that they are a person with a mental disability, the facts offered to support the claim may be exaggerated, leading to the "parade of horribles" often complained of by disability rights advocates.

296. Restatement (SEcond) of Contracts $\$ 177$ (Am. Law Inst. 1981) (requiring that the susceptible party be dominated by the other, or to have such a relationship that the weaker is justified in believing that the other party will not take advantage of her). 1966).

297. Odorizzi v. Bloomfield Sch. Dist., 54 Cal. Rptr. 533, 540 (Cal. Ct. App.

298. Id.

299. Id. at 537.

300. Id. at 543.

301. See Weihofen, supra note 44, at 225; Beane v. Stroope, 141 S.W.2d 537, 538 (Ark. 1940); Fewkes v. Borah, 35 N.E.2d 69, 72 (Ill. 1941) (illustrating that courts will use a combination of personal factors to determine the mental condition of a litigant).

302. See Waterman v. Whitney, 11 N.Y. 157, 165 (1854); Green, supra note 293, at 191. 
Only pleading undue influence would arguably yield benefits for people with mental disabilities. The level of mental impairment required to show undue susceptibility is lower than it is for mental incapacity. For example, medical expertise is not necessary to support the claim. This lower burden of proof makes it easier for people with mental disabilities to use this doctrine. Because the impairment need not be as significant as under mental incapacity, undue influence need not call on stereotypic portrayals of mental disability. The claimant can avoid being portrayed as unkempt, irrational, or delusional. The plaintiff in Odorizzi did not have to demonstrate his weakened state by describing whether he had recently showered, was hearing voices, or had recently donated money to the Black Panthers. ${ }^{303} \mathrm{He}$ was able to describe the circumstances that caused him emotional anguish, but he was not required to show how that anguish manifested itself.

Additionally, the mental weakness of the claimant is but one factor the fact finder may use to determine undue susceptibility. ${ }^{304}$ Other factors may include the physical condition of the claimant, her age, her emotional state, and the circumstances that may have led to the emotional her vulnerability. For instance, in Eldridge $v$. May, ${ }^{305}$ a spouse challenged her husband's contractual grant of a significant portion of the couple's assets to the husband's sister. She based part of her challenge on undue influence. The case described the vulnerable spouse as "73 years of age, broken in health, and somewhat enfeebled in mind. He had valvular disease of the heart and kidney trouble. Dropsy had set in . . . he had become childish and fretty and there was a degeneration of his mental faculties." ${ }^{306}$ The court went on to describe the circumstances under which the documents were signed, including how the sister deliberately separated her brother from his wife to facilitate the execution of the documents, her brother's lack of access to counsel, and the sister's complete manipulation of her brother to ensure he was isolated and under her control. ${ }^{307}$ The consideration of many factors

303. Allore v. Jewell, 94 U.S. 506, 508 (1876) (describing deceased as uncleanly); Flagstaff Realty v. Ned, 544 A.2d 385, 386 (N.J. Super. Ct. App. Div. 1897) (describing defendant as having hallucinations); Fingerhut v. Kralyn Enters., Inc., 337 N.Y.S.2d 394, 403 (N.Y. Sup. Ct. 1971) (describing plaintiff's strange behavior and donation to Black Panthers).

304. See In re Jackson v. Schrader, 676 N.W. 2d 599, 604 (Iowa 2003); In re Estate of Baessler, 561 N.W.2d 88, 92 (Iowa Ct. App. 1997); Estate of Welch, 534 N.W. 2d 109, 112 (Iowa Ct. App. 1995); DesMarais v. Desjardins, 664 A.2d 840, 843 (Me. 1995); Russo v. Miller, 559 A.2d 354, 357 (Me. 1989).

305. Elridge v. May, 150 A. 378, 378 (Me. 1930).

306. $I d$. at 380 .

307. See id. at $380-82$. 
led to a more holistic assessment of the vulnerability of the claimant rather than just focusing on his mental state. This disincentivizes the exaggeration of the claimant's mental weakness.

The second prong required to establish a claim of undue influence is over persuasion or undue pressure. As to the second element, the court in Odorizzi identified the following factors to help determine when a party has applied undue pressure:

Over persuasion is generally accompanied by certain characteristics which tend to create a pattern. The pattern usually involves several of the following elements: (1) discussion of the transaction at an unusual or inappropriate time, (2) consummation of the transaction in an unusual place, (3) insistent demand that the business be finished at once, (4) extreme emphasis on untoward consequences of delay, (5) the use of multiple persuaders by the dominant side against a single servient party, (6) absence of third-party advisers to the servient party, (7) statements that there is no time to consult financial advisers or attorneys. If a number of these elements are simultaneously present, the persuasion may be characterized as excessive. ${ }^{308}$

A person with a mental disability can certainly use undue pressure to police agreements in which the competent party has overreached in some manner. The Odorizzi factors, as well as the need to establish the competent party was in a position of dominance visa-vis the claimant, ${ }^{309}$ narrow the doctrine of undue influence for claimants with mental disabilities. The factors are not binding, but they do appear frequently in cases involving undue influence. Thus, unlike mental incapacity, it is not sufficient to establish questionable mental capacity. The claimant must go further and persuade the fact finder that the other party actively took advantage of her and was in a position of dominance. The claimant must show facts other than mental state to justify contract avoidance. Arguably, the claimant's burden is heavier, and it may make contract avoidance less likely.

For instance, it is unlikely the plaintiff in Renchard could have relied successfully on the undue influence doctrine to avoid his contract with defendants. Nothing in the facts indicated he was in a weakened state when he entered into the various contracts at issue. Additionally, no facts indicated the defendant used undue pressure

308. See Odorizzi v. Bloomfield Sch. Dist., 54 Cal. Rptr. 533, 540 (Cal. Ct. App. 1966).

309. Professor Eisenberg argues persuasively that unfair persuasion should be a defense to contract enforcement regardless of the relationship of the parties. See Eisenberg, supra note 13, at 773-78. 
to persuade the plaintiff to enter into those contracts. The result in the case would have been different if the plaintiff relied on the doctrine of undue influence, and absent the mental incapacity doctrine, there was no basis for avoiding the contract.

Such a result may be acceptable. If a claimant pleads undue influence and mental incapacity is no longer available, the reinforcement of stereotypes about mental disability can be avoided. Defining mental disability is challenging; it is fluid, nuanced, and complex. It is an assessment that court's may not be competent to make which makes limiting the scope of doctrine of mental incapacity attractive. ${ }^{310}$ Additionally, undue influence is not as stigmatizing as mental incapacity. Anyone, not just people with mental disabilities, can have a moment of weakness in certain circumstances. Further, undue influence is unlikely to deter vendors from entering into contracts with people with mental disabilities out of fear of liability. First, it is likely vendors are well aware of the vulnerability and weakness of the other party. ${ }^{311}$ Second, the second prong of the doctrine focuses on the actions of vendors, over which they have complete control. Thus, any liability incurred results from actions vendors took, rather than the questionable capacity of the other contracting party.

That the undue influence doctrine places a heavier burden on the person with a mental disability may make it more appealing to disability rights activists. It shrinks the blanket of protection provided by the mental incapacity doctrine and thus may lead to more accountability for people with mental disabilities. This seems consistent with the dignity of risk principle and the goals of the ADA. Further, undue influence is consistent with the goals of the DRM and the ADA because it seeks to prevent one person from taking unethical advantage of another, regardless of whether either party has a disability. ${ }^{312}$ Anyone, disabled or not, may be subject to the unethical conduct of someone with whom they are in a quasi-fiduciary relationship. Thus, the doctrine offers protection for everyone, not just people with mental disabilities.

310. See, e.g., Nat'l Council on Disability, supra note 18 , at 73 . The evolving definition of disability as a social construct rather than exclusively a medical condition is beyond the scope of this essay. However, the social model of disability and its rejection of the medical model are serious challenges to the mental incapacity doctrine, which adopts solely a medical model of disability.

311. See Richard A. Epstein, Unconscionability: A Critical Reappraisal, 18 J. L. \& ECON. 293, 303 (1975).

312. Green, supra note 293, at 182. 


\section{B. Unconscionability}

A second contract doctrine that may provide a substitute for mental incapacity is the doctrine of unconscionability. ${ }^{313}$ A claimant may use unconscionability to invalidate a clause or an entire contract. Generally, a claimant seeking to avoid enforcement of an unconscionable term or contract must establish two elements: 1) the provision or clause is substantively unconscionable; and 2) the contract or provision is procedurally unconscionable. ${ }^{314}$ Most jurisdictions require some quantum of each, although they need not be evenly divided. ${ }^{315}$ Substantive unconscionability is an amorphous concept. It generally asks whether a term or the contract itself is somehow oppressive or unduly harsh. Procedural unconscionability goes to the manner in which the parties entered into the contract.

Substantive unconscionability goes to the very heart of the transaction. It questions the content of the contract rather than the process by which the parties entered into it. It invites an assessment of the term or the entire contract based on social and economic mores. Substantively unconscionable terms are those that are so one-sided they are oppressive or create unfair surprise on the part of the claimant. ${ }^{316}$ Courts, in many cases involving mental incapacity, implicitly or explicitly measure the substance of the transaction against concepts of what is commercially fair and reasonable, which is what substantive unconscionability expressly allows a court to do.

A person with disabilities can use facts to establish procedural unconscionability. Procedural unconscionability refers to some defect in the process of contracting. Factors the courts use to assess

313. The doctrine of unconscionability is codified in Section 2-302 of the Uniform Commercial Code and in Section 208 of the Restatement (SECOND) of CONTRACTS.

314. Arthur Leff, Unconscionability and The Code-The Emperor's New Clause, 115 U. PA. L. REv. 485, 487 (1967) (distinguishing between "bargaining naughtiness" i.e., procedural unconscionability, and overly harsh terms, i.e., substantive unconscionability); see also Williams v. Walker-Thomas Furniture Co., 350 F.2d 445, 449 (D.C. Cir. 1965); Telecom Intern. Am., Ltd. v. AT\&T Corp., 280 F.3d 175, 194 (2d Cir. 2001); A\&M Produce Co. v. FMC Corp., 186 Cal. Rptr. 114, 121 (Ct. App. 1982).

315. See Harrington v. Atl. Sounding Co., Inc., 602 F.3d 113, 129 (2d Cir. 2010); Gatton v. T-Mobile USA, Inc., 61 Cal. Rptr. 3d 344, 350 (Cal. Ct. App. 2007); Brown v. Genesis Healthcare Corp., 729 S.E.2d 217, 227 (W. Va. 2012). But see Hatkoff v. Portland Adventist Med. Ctr., 287 P.3d 1113, 1118 (Or. 2012) (requiring only substantive unconscionability); WILLISTON, supra note 43, § 18:10; Modern Law of Contracts § 19:41.

316. Maxwell v. Fidelity Fin. Serv., Inc., 907 P.2d 51, 58 (Ariz. 1995) (citing to Res. Mgmt. Co. v. Weston Ranch \& Livestock Co., 706 P.2d 1028, 1041 (Utah 1985)). 
procedural unconscionability include whether the contract was offered on a take it or leave it basis without the ability to negotiate the terms, ${ }^{317}$ whether it was written in legalese, ${ }^{318}$ whether a provision was hidden or inconspicuous due to its location or lack of heading or other formatting failures, ${ }^{319}$ or whether there was unequal bargaining power between the parties. ${ }^{320}$

As with undue influence, it is unlikely that unconscionability would have saved the plaintiff from his contract obligations in Renchard, although there are some facts that may have allowed plaintiff to plead it. The facts do not support a claim of substantive unconscionability. The plaintiff did not challenge the terms of the contracts as being unduly oppressive or commercially unreasonable. Plaintiff might have had a colorable claim of procedural unconscionability, however. In his complaint he alleged he was unable to understand sophisticated language. ${ }^{321}$ If the contract terms concerning the defendant's right to seize and sell the yacht were hidden or written in legalese or the plaintiff was unable to have an advisor review the documents, then Mr. Renchard could claim procedural unconscionability. However, had the facts supported such a claim, it is likely Mr. Renchard would have included it in his initial pleadings. As with undue influence, the outcome of the case would have been different without the mental incapacity doctrine, resulting in the enforcement of the contracts against the plaintiff in Renchard.

Both unconscionability and mental incapacity frequently arise in the consumer context. ${ }^{322}$ Plaintiffs have challenged loans, mortgages, and other financial transactions under the doctrine of unconscionability and not the mental incapacity doctrine. ${ }^{323}$ On its face,

317. See Williams v. Walker-Furniture Co., 350 F.2d 445, 449-50; DJ Coleman, Inc. v. Nufarm Ams., Inc., 693 F. Supp. 2d 1055, 1073 (S.D.N.D. 2010); Am. Home Improvement Co. v. Maclver, 201 A.2d 886 (N.H. 1964); Frostifresh Corp. v. Reynoso, 274 N.Y.S. 2d 757, 759 (N.Y. 1966), rev'd on other grounds, 281 N.Y.S. 2d 964, 965 (N.Y. App. Div. 1967).

318. See Walker-Furniture Co., 350 F.2d at 449; John Deere Leasing Co. v. Blubaugh, 636 F. Supp. 1569, 1573 (D. Kan. 1986).

319. See Tompkins v. 23andMe, Inc., No. 5:13-CV-05682-LHK, 2014 WL 2903752, at *14 (N.D. Cal. June 25, 2014), aff'd, 840 F.3d 1016, 1020 (9th Cir. 2016); Blubaugh, 636 F. Supp. at 1572-73.

320. See Blubaugh, 636 F. Supp. at 1573; A\&M Produce Co. v. FMC Corp., 186 Cal. Rptr. 114, 122 (Cal. Ct. App. 1982); Allen v. Mich. Bell Tel. Co., 171 N.W.2d 689, 692 (Mich. Ct. App.1969); Frostifresh Corp., 274 N.Y.S. 2d at 759.

321. See Renchard v. Prince William Marine Sales, Inc., 28 F. Supp. 3d 1, 6 (D.D.C. 2014).

322. See, e.g., FARnsworth, supra note 11, at 102; Hunter, supra note 45, $\S 19: 43$.

323. See generally In re Tillette, 557 B.R. 902 (Bankr. S.D.W. Va. 2016); Webb v. First Tenn. Brokerage, Inc., No. E2012-00934-COA-R3CV, 2013 WL 3941782, *1 
unconscionability requires an objective, rather than subjective, analysis. Neither element of unconscionability involves an inquiry into the mental state of the claimant. Thus, the doctrine avoids one of the challenges presented by both mental incapacity and undue influence. As with undue influence, the appeal of unconscionability is its universality; it does not single out people with mental disabilities. In establishing unconscionability, a claimant may raise her lack of education, financial sophistication, ${ }^{324}$ or command of the English language. ${ }^{325}$ Anyone may suffer from what Professor Eisenberg calls "transactional incapacity," 326 which leads to a claim for relief based on unconscionability.

The appeal of these doctrines is that they do not discriminate between people with mental disabilities and those without mental disabilities. Anyone can be in an unduly susceptible state. The impaired and unimpaired alike can be victims of substantive and procedural unconscionability. Employing these doctrines instead of the mental incapacity doctrine enhances the public policy goals of the ADA and the DRM. These doctrines avoid reinforcing stereotypes, honor the dignity of risk principle, and evade the potential conflict between the ADA and the mental incapacity doctrine. Although these doctrines may serve as substitutes for the mental incapacity doctrine, they require strong evidence of wrongdoing on the part of the party contracting with the party with a mental disability. ${ }^{327}$ They are exceptional doctrines and, absent wrongdoing, may leave a person with a mental disability liable for an injudicious contract. $^{328}$

\section{CODA}

In crafting this essay, my intent is not to offer a definitive solution to a definitive problem. Rather, this essay is an invitation to converse about how contract law should consider the voices of

(Tenn. Ct. App. 2013) (challenging opening of brokerage account on the basis of unconscionability).

324. See Webb, 2013 WL 3941782 at *11; A\&M Produce Co., 135 Cal. App. 3d at $118-19$.

325. See Perez v. DirecTV Group Holdings, LLC, 251 F. Supp. 3d 1328, 1333-34 (C.D. Cal. 2017); Hialeah Automotive v. LLC. Basulto, 22 So. $3 d 586$ (Fla. Dist. Ct. App. 2009), review granted, 116 So. 3d 1259 (Fla. 2013), and decision quashed, 141 So. 3d 1145 (Fla. 2014); Frostifresh Corp., 274 N.Y.S. 2d 757, judgment rev'd on other grounds, 281 N.Y.S. 2d 964 (N.Y. App. Term 1967).

326. Eisenberg, supra note 13, at 763-73.

327. See Wendy Chung Rossiter, No Protection for the Elderly: The Inadequacy of the Capacity Doctrine in Avoiding Unfair Contracts Involving Seniors, 78 Or. L. Rev. 807, 810 (1999).

328. $I d$. 
those historically unheard: individuals with mental disabilities. Common law evolves slowly. My intention is to nudge the law forward by encouraging activists, scholars, educators, and jurists to reconsider the appropriateness of an old doctrine in light of changed social, political, and economic circumstances. The mental incapacity doctrine imagines what people with disabilities may want. My goal is to shift the focus from legal imagination to the actual demands of disability rights activists and self-advocates. Let the law hear their demands, consider their perspectives, honor their values, and construct a rule accordingly. 